\title{
Employers' willingness to invest in the training of temporary workers: a discrete choice experiment
}

Citation for published version (APA):

Poulissen, D., de Grip, A., Fouarge, D., \& Künn, A. (2021). Employers' willingness to invest in the training of temporary workers: a discrete choice experiment. ROA. ROA Research Memoranda No. 003 https://doi.org/10.26481/umaror.2021003

Document status and date:

Published: 27/05/2021

DOI:

10.26481/umaror.2021003

Document Version:

Publisher's PDF, also known as Version of record

\section{Please check the document version of this publication:}

- A submitted manuscript is the version of the article upon submission and before peer-review. There can be important differences between the submitted version and the official published version of record.

People interested in the research are advised to contact the author for the final version of the publication, or visit the DOI to the publisher's website.

- The final author version and the galley proof are versions of the publication after peer review.

- The final published version features the final layout of the paper including the volume, issue and page numbers.

Link to publication

\footnotetext{
General rights rights.

- You may freely distribute the URL identifying the publication in the public portal. please follow below link for the End User Agreement:

www.umlib.nl/taverne-license

Take down policy

If you believe that this document breaches copyright please contact us at:

repository@maastrichtuniversity.nl

providing details and we will investigate your claim.
}

Copyright and moral rights for the publications made accessible in the public portal are retained by the authors and/or other copyright owners and it is a condition of accessing publications that users recognise and abide by the legal requirements associated with these

- Users may download and print one copy of any publication from the public portal for the purpose of private study or research.

- You may not further distribute the material or use it for any profit-making activity or commercial gain

If the publication is distributed under the terms of Article $25 \mathrm{fa}$ of the Dutch Copyright Act, indicated by the "Taverne" license above, 


\section{Maastricht University $\$$ ROA}

Employers' willingness to invest in the training of temporary workers: a discrete choice experiment

Davey Poulissen

Andries de Grip

Didier Fouarge

Annemarie Künn-Nelen

\section{ROA Research Memorandum}

ROA-RM-2021/3

Researchcentrum voor Onderwijs en Arbeidsmarkt | ROA Research Centre for Education and the Labour Market / ROA 


\section{Employers' willingness to invest in the training of temporary workers: a discrete choice experiment}

Davey Poulissen

Andries de Grip

Didier Fouarge

Annemarie Künn-Nelen

ROA-RM-2021/3

May 2021

Research Centre for Education and the Labour Market

Maastricht University

P.O. Box 616, 6200 MD Maastricht, The Netherlands

$\mathrm{T}+31433883647 \mathrm{~F}+31433884914$

secretary-roa-sbe@maastrichtuniversity.nl

www.roa.nl

ISSN: 2666-8823 


\section{Abstract \\ Employers' willingness to invest in the training of temporary workers: a discrete choice experiment*}

Various studies have shown that temporary workers participate less in training than those on permanent contracts. Human resources practices are considered to be an important explanation for this difference. We develop a theoretical framework for employers' provision of training that explicitly incorporates the costs and benefits associated with training investments in employees with different types of employment contracts. Our framework not only predicts employers to be less willing to invest in temporary workers due to the shorter time horizon associated with such an investment, but it also provides insights into how this willingness depends on characteristics of the training that are related to the expected costs and benefits of the training investment. A discrete choice experiment is used to empirically test the predictions from our theoretical framework. In line with our theoretical framework, we find that employers are less likely to invest in the training of temporary workers. This particularly holds when temporary workers do not have the prospect of a permanent contract with their current employer. Furthermore, we show that employers' likelihood of investing in temporary workers indeed depends on aspects related to the costs and benefits of training, that is, a financial contribution to the training costs made by employees, a repayment agreement that applies when workers leave the organisation prematurely, and the transferability of the skills being trained. Our findings can be used to increase employers' willingness to invest in temporary workers. However, similar effects are observed when looking at employers' willingness to invest in permanent workers, suggesting that it will be difficult to decrease the gap in employers' willingness to invest between temporary and permanent workers.

JEL classification: J24, J41, J62

Keywords: flexible contracts, human capital investments, stated preference experiment, cost-benefit assessment

Davey Poulissen

Maastricht University

ROA

P.O. Box 616

NL-6200 MD Maastricht

The Netherlands

d.poulissen@maastrichtuniversity.nl
Andries de Grip

Maastricht University

ROA

P.O. Box 616

NL-6200 MD Maastricht

The Netherlands

a.degrip@maastrichtuniversity.nl and IZA

\footnotetext{
We gratefully acknowledge research funding from the Netherlands Initiative for Education Research (NRO) [2016; file number 405-16-402]. We thank Arjan Non and Bart de Koning, as well as the participants of the EALE conference (2018); the Belgian Day for Labour Economists (2019); the CVER Conference at LSE (2019), the second BIBB Conference on the Economics of Vocational Education and Training (2019) and the Nederlandse Arbeidsmarktdag (2019) for their valuable comments.
} 
Didier Fouarge

Maastricht University

ROA

P.O. Box 616

NL-6200 MD Maastricht

The Netherlands

d.fouarge@maastrichtuniversity.nl and IZA
Annemarie Künn-Nelen

Maastricht University

ROA

P.O. Box 616

NL-6200 MD Maastricht

The Netherlands

a.kuenn@maastrichtuniversity.nl and IZA 


\section{Introduction}

Various studies have shown that workers with a temporary employment contract participate less in training than workers with a permanent contract (Arulampalam \& Booth, 1998; Ferreira, De Grip, \& Van der Velden, 2018; Finegold, Levenson, \& Van Buren, 2005). This persistent gap in training participation between temporary and permanent workers hampers the skill development of temporary workers (Booth, Francesconi, \& Frank, 2002). Moreover, since training investments are an important determinant of workers' employability (De Grip, Van Loo, \& Sanders, 2004; International Labour Organization, Organisation for Economic Co-operation and Development, \& World Bank, 2016), temporary workers' lack of training potentially even harms their labour market perspectives, particularly when they fail to keep their skills up-to-date in a labour market that is rapidly changing. From a macro perspective, the lack of training participation among temporary workers could also be considered inefficient, since it hinders the development of a well-trained workforce.

The literature focusing on potential explanations for the relatively low training participation of temporary workers is mainly theoretical. One explanation for the lower training participation of temporary workers could be that employers are less willing to invest in temporary workers. Human capital theory predicts smaller returns to training investments in temporary workers compared to similar investments in permanent workers, because investments in temporary workers are associated with a shorter time horizon, that is, a shorter period in which the organisation benefits from the increased productivity resulting from the investment (e.g. Crawford, 1988; Crawford, 1990). However, this theoretical explanation does not provide direct insights into how training participation among this increasing group of temporary workers can be improved.

This paper aims to investigate whether the willingness of employers to invest in the training of temporary workers can be increased by changing the characteristics that are related to the expected costs and benefits of the training. We therefore develop a theoretical framework that, by focusing on the costs and benefits of training investments in different types of workers, not only leads to predictions of employers' willingness to invest in temporary versus permanent workers, but also provides insights into how the willingness to invest in temporary workers depends on cost-benefitrelated training characteristics. Subsequently, we use a discrete choice experiment to test the predictions from our theoretical framework.

In our discrete choice experiment, employers are asked in three consecutive rounds to indicate to which of two hypothetical workers they would offer a two-day training course costing $€ 2,000$. In each round, the type of contract for both workers is varied randomly to measure employers' willingness to invest in temporary versus permanent workers. Additionally, we randomly vary three training investment characteristics that affect the cost-benefit assessment employers make in their decision. This approach enables us to investigate the extent to which the willingness to invest in temporary workers can be improved. First, the financial contribution the employee is making to cover the costs of training is varied. A financial contribution immediately reduces the employer's out-of-pocket costs of training and is therefore expected to make the investment more attractive. Second, we include the possibility of a repayment agreement in case the worker quits the organisation before the end of the contract. This agreement ensures employers that (part) of the training costs will be reimbursed when workers leave the organisation within a prespecified period. It also increases the expected benefits 
from training by lowering the risk of a worker leaving the organisation before the organisation can reap the full benefits of the training investment. Last, we vary the transferability of the skills being trained. Firm-specific training increases the workers' productivity only within the current organisation and is therefore expected to 'bind' a worker to the employer and prevent the worker from leaving the organisation soon after the training ends (Becker, 1975; Loewenstein \& Spletzer, 1997; Sieben, 2007). Hence, firm-specific training will increase the expected benefits from training. ${ }^{1}$

Our study contributes to the literature on employer investments in training and the literature on the training participation of temporary workers in two ways. First, we are the first to directly measure employers' willingness to invest in temporary versus permanent workers. Previous studies have already shown that temporary workers receive less employer-funded training (Forrier \& Sels, 2003; Fouarge, De Grip, Smits, \& De Vries, 2012; Sauermann, 2006). Fouarge et al. (2012) show that the overall gap in training participation between temporary and permanent workers is merely due to this lack in employer-funded training. Other studies find that the gap between permanent and temporary workers persists after controlling for a set of personal, employer-, and job-related characteristics (Jonker \& De Grip, 1999) or after controlling for selection into organisations that do not provide any training at all (Albert, García-Serrano, \& Hernanz, 2005; Oosterbeek, 1996). Similarly, a related stream of literature has shown that temporary workers more often pay for training themselves and more often follow training in leisure time than workers with a permanent contract (Finegold et al., 2005; Forrier \& Sels, 2003; Jonker \& De Grip, 1999; Sauermann, 2006). All these studies suggest that employers are less willing to invest in or pay for the training of temporary workers compared to permanent workers, though they cannot rule out that the findings are - at least partly - driven by a lower willingness among temporary employees themselves to take up the training being offered to them. Our discrete choice experiment, in contrast, does enable us to draw conclusions on employers' willingness to invest in the training of temporary workers by investigating employers' preferences in a randomised experiment.

Second, we empirically show which cost-benefit-related characteristics of the training explain the presumed lower willingness among employers to invest in temporary workers. This approach provides important insights on how to increase employers' willingness to provide training to temporary workers. Due to the randomized design of our discrete choice experiment, we avoid potential endogeneity, which would arise when using observational data in this regard.

Our results show that employers are indeed less willing to invest in the training of temporary workers compared to permanent workers and that this gap is widest for temporary workers without prospects of a permanent contract with their current employer. Moreover, our results illustrate that employers are responsive to changes in aspects of the training that are related to the cost-benefit assessment underlying employers' investment decision. This holds for employers' willingness to invest in permanent as well as temporary workers. Employers' willingness to invest in temporary workers can

1. Note that early human capital theory assumes that employers are unwilling to invest in general skills, since all the benefits from the training are expected to accrue to the employee. This also implies the type of contract would have no influence on the provision of general training. However, current human capital theory acknowledges that, in practice, organisations often do provide general training when (1) they have monopsony power, which ensures they can reap part of the benefits from the investment (Booth \& Zoega, 2000), (2) when they use general training to screen employees (Autor, 2001), or (3) when the general training is accompanied by firm-specific training (Lazear, 2009). In these cases, the type of contract would therefore even be relevant when general training is offered. 
therefore be increased by altering these aspects. First, our results show that employers are more likely to invest in temporary employees when the expected benefits from such an investment are increased by making the training firm specific rather than transferable. Second, implementing an agreement where employees must pay back (part of) the training costs in case they leave the organisation within a prespecified time also increases employers' willingness to invest in temporary workers, by both increasing the expected benefits and lowering the expected costs of the investment. Third, asking temporary workers to make a financial contribution also increases employers' willingness to invest in them, by directly lowering the employer's costs. ${ }^{2}$

Changing one or more of these training investment characteristics for temporary workers only - or changing them to a larger extent for temporary workers - will substantially increase employers' willingness to invest in temporary versus permanent workers, although fully closing the gap in employers' preference to invest between permanent and temporary workers will remain difficult. The latter particularly holds for temporary workers with no prospects of a permanent contract. For these workers, a large financial contribution (€400) must be combined with a full repayment agreement $(100 \%)$ to fully close the training gap with permanent workers who are not subject to a financial contribution or repayment agreement. To fully close the training gap between temporary workers who do have prospects of a permanent contract and permanent workers, either a financial contribution of $€ 200$ or a $50 \%$ repayment agreement is (more than) sufficient.

The remainder of this paper is structured as follows. Section 2 provides the theoretical framework for the provision of training to different types of employees. Section 3 describes the data, the discrete choice experiment, and the empirical strategy. In Section 4 we present our results, and Section 5 concludes the paper.

\section{An investment framework for the provision of training}

We assume organisations have a training fund with limited resources. Organisations must therefore choose which employees to offer training to in order to maximise their expected return.

The characteristics of the employees, the employers, and the type of training being offered jointly determine the expected return via their effects on the costs and/or benefits associated with the training. The higher the benefits and the lower the costs, the higher the expected return derived from the investment. The investment opportunity with the highest return (present value of training benefits minus training costs) will yield the highest return and will therefore be the preferred investment opportunity. When a permanent (PERM) and temporary (TEMP) worker are competing for training, the probability that the employer will select the temporary worker $\left(\operatorname{Pr}_{T E M P, n}\right)$ is therefore equal to

$$
\operatorname{Pr}_{\mathrm{i}}=\mathrm{TEMP}, \mathrm{n}=\operatorname{Pr}\left(\text { RETURN }_{\mathrm{i}=\text { TEMP }, \mathrm{n}} \geq \text { RETURN }_{\mathrm{i}=\text { PERM,n })}\right) \text {. }
$$

Using Equation (1), we can formulate expectations regarding employers' willingness to invest in temporary workers based on the costs and benefits associated with training a temporary or permanent worker, as well as the extent to which certain characteristics of the training investment could be changed to increase employers' willingness to invest in temporary workers.

2. It should be noted that the latter effect is strongest for temporary workers with prospects of a permanent contract. 


\section{Costs and benefits of training}

According to standard human capital theory (Becker, 1975), the total costs of training for the employer depend on 1) the share of direct training costs that is paid by the employer, 2) the opportunity costs of training, which usually consist of foregone productivity when the training takes place during work time, and 3) the expected increase in labour costs (equal to the wage premium for trained workers). The cost function of a specific training investment could therefore be specified as follows:

$$
\text { COSTS }=(\overbrace{}^{D-F})+\underbrace{\mathrm{K}+\sum_{\mathrm{t}=1}^{\infty}\left(\frac{\mathrm{W}_{\mathrm{s}}^{*}-\mathrm{W}}{(1+r)^{t}}\right) \operatorname{Pr}(\mathrm{z}=1 \mid \mathrm{t}, \mathrm{c}, \mathrm{s}, \mathrm{a})}_{\text {Indirect costs of training for the employer }} \text {. }
$$

The first term on the right-hand side represents the difference between the total direct costs of the training $(D)$ and the financial contribution made by the employee $(F)$. It therefore constitutes the direct out-of-pocket costs of the training borne by the employer. The second term, $K$, refers to the opportunity costs of training, and the third term refers to the expected increase in labour costs, where $W$ refers to the employee's future wages when the employee does not receive the training and $W_{s}^{*}$ refers to the situation in which the employee does receive the training, with the difference being equal to the wage premium for training. The subscript $s$ in $W_{s}^{*}$ denotes the specificity of the training offered. We assume that $W_{\text {general training }}^{*}>W_{\text {firm-specific training, because workers will be able to capture }}^{*}$ a larger part of the returns to training when the training also has productive value at other organisations (Becker, 1975). ${ }^{3}$ The higher wage resulting from training must be paid for every future period in which the employee is still working for the organisation. We therefore use the real market interest rate $(r)$ to calculate the present value of the wage differential and multiply the result with the probability of the employee continuing to work for the organisation $(\operatorname{Pr}(z=1 / t, c, s, a))$ for every period $t$ and then take the sum of this series. ${ }^{4}$

The training benefits for the employer depend on 1) the expected increase in productivity as a result of providing the training and 2) the expected time horizon of the investment, which is equal to the period the employee is expected to stay employed at the organisation. In addition, employers who train their employees could receive a (partial) reimbursement of the training costs when a repayment agreement applies to an employee quitting within a predetermined period after the training ends. The benefit function of a training investment could therefore be specified as follows:

3. In some models, employers can also offer a lower (starting) wage during the initial training phase, especially when investing in general skills (Barron \& Berger, 1999; Mincer, 1962), which would basically have the same effect.

4. Note that this probability depends on the employee's type of contract $(c)$, the specificity of the training offered $(s)$, and the repayment agreement that applies when the employee leaves the organisation prematurely (a) (see below). 


$$
\begin{aligned}
\text { BENEFITS } & =\sum_{\mathrm{t}=1}^{\sum_{\infty}^{\infty} \frac{\delta^{t}\left(Q^{*}-Q\right) P \cdot \operatorname{Pr}(\mathrm{z}=1 \mid \mathrm{t}, \mathrm{c}, \mathrm{s}, \mathrm{a})}{(1+\mathrm{r})^{\mathrm{t}}}} \\
& +\underbrace{}_{\frac{\mathrm{a}(\mathrm{D}-\mathrm{F})}{(1+\mathrm{r})^{t}}(1-\operatorname{Pr}(\mathrm{z}=1 \mid \mathrm{t}=\mathrm{c}, \mathrm{s}, \mathrm{a})) .}
\end{aligned}
$$

Reimbursement of training costs due to repayment agreement

The first term on the right-hand side represents the expected increase in productivity summed over the entire investment horizon. In the numerator, the difference in the employee's potential output with and without receiving training $\left(Q^{*}\right.$ and $Q$, respectively) is calculated at market prices $(P)$. Since training can show diminishing returns over time, for example, because the skills trained can deteriorate over time (Welch \& Ureta, 2002), this expected increase in market output is multiplied by a skill depreciation coefficient $\left(\delta^{t}<1\right)$. Since the employer can only reap the benefits from the training if the employee continues working for the organisation, we multiply the expected increase in productivity for every period $t$ with the probability that the employee continues working at the organisation, given the employee's contract type, the specificity of the training offered, and the repayment agreement that applies if the employee leaves the organisation voluntarily within a predetermined period after the training ends. In the denominator, the present value of all future benefits from training is calculated using the discount factor $(r) .^{5}$

The second term on the right-hand side of Equation (3) represents the (partial) reimbursement of training costs by the employee leaving the organisation voluntarily before a predetermined period after the training ends. The strictness of the repayment agreement is given by $a$, the percentage of training costs that must be reimbursed, which makes $(D-F) a$ the total financial reimbursement. Because this repayment will be collected $t$ periods after the training, this amount is discounted by $(1+r)^{t}$.

The probability of an employee continuing to work for the organisation $(\operatorname{Pr}(z=1 / t, c, s, a))$ plays an important role in both the costs and benefits of training and depends on three variables: the employee's contract type $(c)$, the specificity of the training offered $(s)$, and the applicable repayment agreement.

Regarding the impact of the type of contract on $\operatorname{Pr}(z=1 / t, c, s, a)$, we assume that

$$
\operatorname{Pr}(\mathrm{z}=1 \mid \mathrm{t}, \mathrm{c}=\mathrm{TEMP}, \mathrm{s}, \mathrm{a})<\operatorname{Pr}(\mathrm{z}=1 \mid \mathrm{t}, \mathrm{c}=\operatorname{PERM}, \mathrm{s}, \mathrm{a}) .
$$

Temporary workers will, on average, leave the organisation sooner than workers with a permanent contract. This could happen because their contract expires, because they anticipate the expiry of their

5. Note that the skill depreciation coefficient $\left(\delta^{t}\right)$ and the discount rate $(r)$ ensure that the first years after receiving training are the most important in determining total training benefits. 
contract (e.g. by leaving the organisation early), or because they are offered a better job somewhere else. ${ }^{6}$ Hence, Equation (4) should hold.

Regarding the impact of the specificity of the training on $\operatorname{Pr}(z=1 \mid t, c, s, a)$, we assume that

$$
\operatorname{Pr}(\mathrm{z}=1 \mid \mathrm{t}, \mathrm{c}, \mathrm{s}=\text { firm }- \text { specific, } \mathrm{a})<\operatorname{Pr}(\mathrm{z}=1 \mid \mathrm{t}, \mathrm{c}, \mathrm{s}=\text { transferable, } \mathrm{a}) .
$$

Transferable skills also have productive value in other organisations, which is why they are likely to increase the probability of a worker leaving the organisation. Hence, Equation (5) should hold.

Regarding the impact of repayment agreements on $\operatorname{Pr}(z=1 / t, c, s, a)$, we assume that

$$
\operatorname{Pr}\left(\mathrm{z}=1 \mid \mathrm{t}, \mathrm{c}, \mathrm{s}, a_{1}\right)<\operatorname{Pr}\left(\mathrm{z}=1 \mid \mathrm{t}, \mathrm{c}, \mathrm{s}, a_{2}\right) \text { if } a_{1}>a_{2} .
$$

A (stricter) repayment agreement will increase the probability of a worker staying at the organisation, since leaving it is now associated with a cost. Hence, Equation (6) should hold.

\section{Employers' willingness to invest in the training of temporary workers}

Subtracting training costs from training benefits to obtain the training returns and substituting the result in Equation (1) yields Equation (7). Faced with a choice between a temporary (TEMP) and a permanent (PERM) employee, the following equation provides insight into the factors that determine the probability of the temporary employee being selected to receive training:

$$
\begin{aligned}
& \operatorname{Pr}_{\text {TEMP,n }} \\
& =\operatorname{Pr}\left(\sum_{\mathrm{t}=1}^{\infty} \frac{\delta^{\mathrm{t}}\left(\mathrm{Q}^{*}-\mathrm{Q}\right) \mathrm{P} \cdot \operatorname{Pr}(\mathrm{z}=1 \mid \mathrm{t}, \mathrm{c}=\mathrm{TEMP}, \mathrm{s}, \mathrm{a})}{(1+\mathrm{r})^{\mathrm{t}}}\right. \\
& +\frac{\mathrm{a}(\mathrm{D}-\mathrm{F} \mid \mathrm{c}=\mathrm{TEMP})}{(1+\mathrm{r})^{\mathrm{x}}}(1-\operatorname{Pr}(\mathrm{z}=1 \mid \mathrm{t}=\mathrm{x}, \mathrm{c}=\mathrm{TEMP}, \mathrm{s}, \mathrm{a})) \\
& -(\mathrm{D}-\mathrm{F} \mid \mathrm{c}=\mathrm{TEMP})-\mathrm{K}-\sum_{\mathrm{t}=1}^{\infty}\left(\frac{\mathrm{W}_{\mathrm{s}}^{*}-\mathrm{W}}{(1+r)^{t}}\right) \operatorname{Pr}(\mathrm{z}=1 \mid \mathrm{t}, \mathrm{c}=\text { TEMP, } \mathrm{s}, \mathrm{a}) \\
& \geq \quad \sum_{\mathrm{t}=1}^{\infty} \frac{\delta^{\mathrm{t}}\left(\mathrm{Q}^{*}-\mathrm{Q}\right) \mathrm{P} \cdot \operatorname{Pr}(\mathrm{z}=1 \mid \mathrm{t}, \mathrm{c}=\text { PERM, } \mathrm{s}, \mathrm{a})}{(1+\mathrm{r})^{\mathrm{t}}} \\
& +\frac{\mathrm{a}(\mathrm{D}-\mathrm{F} \mid \mathrm{c}=\text { PERM })}{(1+\mathrm{r})^{\mathrm{x}}}(1-\operatorname{Pr}(\mathrm{z}=1 \mid \mathrm{t}=\mathrm{x}, \mathrm{c}=\text { PERM, } \mathrm{s}, \mathrm{a})) \\
& \left.-(\mathrm{D}-\mathrm{F} \mid \mathrm{c}=\mathrm{PERM})-\mathrm{K}-\sum_{\mathrm{t}=1}^{\infty}\left(\frac{\mathrm{W}_{\mathrm{s}}^{*}-\mathrm{W}}{(1+r)^{t}}\right) \operatorname{Pr}(\mathrm{z}=1 \mid \mathrm{t}, \mathrm{c}=\text { PERM, } \mathrm{s}, \mathrm{a})\right) \text {. }
\end{aligned}
$$

The market price of the organisation's output $(P)$ as well as the market interest rate $(r)$ are constants that do not differ between the different investment opportunities. Differences in the remaining variables and parameters are thus essential in determining who receives training. We make some simplifying assumptions. We assume that the opportunity costs of training $(K)$, the increase in productivity per hour worked $\left(Q^{*}-Q\right)$, the wage premium due to training $\left(W_{s}^{*}-W\right)$, and the skill

6. For illustration, in 2018 , the average tenure of permanent workers was 12 years in the Netherlands, while the average tenure for those with a flexible contract (e.g. temporary workers and workers without fixed numbers of working hours) was equal to only 2.1 years (Statistics Netherlands, 2019). 
depreciation coefficient $\left(\delta^{t}\right)$ are the same for both temporary and permanent employees. While these variables could differ between temporary and permanent workers in practice - for instance, due to differences in job tasks, average age, average tenure, and other factors that are related to the type of contract - we do not take these differences into account in our theoretical framework. We do this for three reasons. First, from a theoretical perspective, it is not always clear how exactly these factors differ between temporary and permanent workers. Second, we are interested in the effect of the type of contract itself, and not in effects that are driven by various confounding factors. Third, as explained in the next section, our empirical strategy eliminates the effect of these confounding factors by explicitly instructing employers that the employees in the experiment differ only in relation to a list of explicitly mentioned characteristics (e.g. the type of contract) and are otherwise fully identical. Given these assumptions, the probability of an employee staying at the organisation $(\operatorname{Pr}(z=1))$, the specificity of the skills trained $(s)$, the financial contribution made by the employee $(F)$, and the repayment agreements (operationalised by $a$ and $t$ ) determine the utility of a training investment and, hence, which employee will be offered training.

First, we focus entirely on the type of contract and assume no difference in the financial contribution, the specificity of the skills trained, and the repayment agreement (we relax this assumption later). In this case, $\operatorname{Pr}(z=1)$ is the only factor driving the investment decision. A higher value of $\operatorname{Pr}(z=1)$ lengthens the investment horizon of the training investment, which positively impacts the expected returns and, therefore, the probability that a specific employee will be chosen to receive the training.

As stated in Equation (4), temporary workers will, on average, leave the organisation sooner than permanent workers. As long as the other parameters in Equation (7) do not differ between temporary and permanent workers (as assumed above), the expected utility arising from training investments in temporary workers is lower compared to the expected utility from training investments in permanent workers. Based on Equations (4) and (7), we therefore expect that employers are less willing to invest in temporary workers, compared to permanent workers. Similarly, employers are expected to be less willing to invest in temporary employees without prospects of a permanent contract, compared to those who do have such prospects. This short-term interest of the employer might not be in line with the optimal long-term macro balance of ensuring a well-trained workforce, however, when this leads to the underprovision of training at the societal level (Stevens, 2001). It is therefore important to investigate how employers' willingness to train temporary workers can be increased.

\section{Compensatory mechanisms}

As Equation (7) shows, the expected preference among employers to invest in permanent workers could be mitigated by allowing the financial contribution $(F)$, specificity of the skills being trained $(s)$, and the repayment agreement (operationalised by $a$ and $x$ ) to differ between permanent and temporary workers. According to Equation (7), the direct costs of training borne by the employer $(D-F)$ are lowest when investing in the temporary worker if this worker would make a financial contribution and the permanent worker would not. This increases the relative returns from investing in the temporary worker, which, in turn, increases the attractiveness to invest in this worker. If the difference in the financial contributions made by these workers and, therefore, its positive impact on the relative returns of the temporary worker is large enough, it could even shift employers' preference from investing in a worker with a permanent contract to investing in a temporary worker. A financial 
contribution made by temporary workers could therefore act as a compensating mechanism to (partly) compensate for the lesser willingness to invest in temporary workers.

A repayment agreement could also act as a compensatory mechanism. If the temporary worker in our framework would be subject to a repayment agreement while the permanent worker would not (or would be subject to a less strict agreement), this would increase the relative returns of investing in the temporary worker, which would increase willingness to invest in this worker relative to the permanent worker. The repayment agreement would impact the willingness to invest in the temporary worker via two routes. First, a stricter repayment agreement for the temporary worker allows the employer to recoup (part of) the direct training costs when this employee leaves the organisation within $t$ periods after the training ends. By taking away (part) of the risk that the employer will not be able to earn back the initial training investment, investing in this temporary worker becomes more attractive. The stricter the repayment agreement of the temporary worker compared to the permanent worker, the stronger this effect. Second, implementing a repayment agreement could induce a behavioural response. Since leaving the organisation voluntarily within $t$ periods after the training ends is now associated with a direct financial cost for the employee, which makes it less likely that the employee will leave the organisation within this predetermined period. If temporary workers are subject to a repayment agreement while permanent workers are not (or they are subject to a less strict agreement), a repayment agreement shifts the initial lower value of $\operatorname{Pr}(z=1)$ for temporary workers (condition (5)) to a level closer to the value for permanent workers. This would lengthen the investment horizon of investments in temporary workers, thereby increasing the relative returns of investing in them and decreasing the gap in the willingness to invest between temporary and permanent workers.

Finally, offering training that is firm specific instead of transferable also increases the expected returns from training by potentially binding the worker to the organisation for a longer period (which increases $\operatorname{Pr}(z=1)$ ), as well as by enabling employers to capture a larger share of the returns to training (which is why we assumed $W_{\text {general training }}^{*}>W_{\text {firm-specific training }}^{*}$. If these effects are large enough, employers could become more willing to invest in firm-specific training for temporary workers than in transferable training for permanent workers. However, when discussing the compensatory mechanisms that could improve employers' willingness to invest in temporary workers in Section 4, we will focus primarily on the impact of financial contributions and repayment agreements, since firmspecific training is less relevant for temporary workers who must leave the organisation after some time.

\section{Data, experimental design, and empirical strategy}

\section{The data}

Our data stem from a unique survey among Dutch employers: the Employer Training Policy Survey we conducted in 2017. We specifically targeted the survey at those responsible for their organisation's training policy and only contacted organisations employing at least five employees. ${ }^{7}$ This ensured that we only collected responses from relevant decision makers in organisations that employed at least a certain number of workers, increasing the external validity of our results (Hainmueller, Hangartner, \&

7. We used Kantar Public's business panel, which allows for these selections (http://www.nipo.nl/panel/businesspanel). 
Yamamoto, 2015). Within this target group, we aimed for a representative sample based on nine sectors of industry and five firm size classes. Because the response was expected to be somewhat lower for some branches and size classes, we oversampled these organisations in the gross sample. Foundations and (religious) associations/churches were excluded from the sampling procedure. In total, 3,911 organisations were approached, of which 1,032 responded ( $26 \%$ response rate). The distribution of the responses by industry sector and firm size classes for the net sample is displayed in Table 1, where it is also compared to the distribution for the Netherlands as a whole. Across sectors and size classes, the firms in our sample closely match the distribution at the national level, with two minor exceptions. First, there is a slight underrepresentation of the agricultural and cultural sectors, which account for only a small proportion of employment in the Netherlands. Second, large firms with $50+$ employees are somewhat overrepresented in our sample.

\section{$<$ Insert Table 1 here>}

\section{Discrete choice experiment}

The core of the survey is a discrete choice experiment aimed at measuring employers' willingness to invest in workers under varying controlled conditions. Stated preference experiments, such as discrete choice experiments, have traditionally been used in fields such as psychology, marketing, health economics, environmental economics, transportation economics, and human resource management (McFadden et al., 2005; Rao, 2014), but the method is also being increasingly applied in economics and labour economics in particular (e.g. Benjamin, Heffetz, Kimball, \& Szembrot, 2014; Borghans, Romans, \& Sauermann, 2010; Kristensen \& Johansson, 2008; Van Soest \& Vonkova, 2014; Wiswall \& Zafar, 2018). Our discrete choice experiment consists of a paired conjoint study in which employers are asked in three consecutive rounds to determine to which of two hypothetical workers they would offer a two-day (16-hour) training course that costs $€ 2,000$. We include four attributes on which the profiles vary. These attributes and their levels are given in Table $2 .^{8}$ The number of attributes is deliberately kept low to avoid overwhelming the respondents, which would invalidate our results (Malhotra, 1982). In addition, limiting the number of attributes implies that a smaller sample or fewer decision tasks per respondent will suffice. With respect to the underlying levels of the attributes included, we intentionally choose an equal number (three) of levels for each attribute, since studies have shown that attributes with relatively many levels systematically achieve greater importance (Rao, 2014; Verlegh, Schifferstein, \& Wittink, 2002).

\section{$<$ Insert Table 2 here $>$}

With respect to the type of contract, we differentiate between workers with permanent contracts, workers with a two-year temporary contract who have prospects of a permanent contract, and those with a two-year contract who do not have prospects of receiving a permanent contract. ${ }^{9}$ The distinction between temporary workers based on their prospects of obtaining a permanent contract is based on previous research showing that both participation in and provision of training differ

8. Table A1 in Appendix A shows the introductory text of the stated choice experiment and an example of a choice task employers could see in the experiment.

9. We opted for temporary contracts with a fixed term of two years because the maximum duration of temporary contracts in the Netherlands was, in principle, limited to two years at the time of the survey. 
significantly between temporary workers with and those without such prospects (Ferreira, Künn, \& De Grip, 2017; Fouarge et al., 2012).

Varying in the specificity of the skills trained, the financial contribution employees make, and the repayment agreement that applies when employees voluntarily leave the organisation within one year after the training ends enable us to investigate whether the expected preference to invest in permanent workers is influenced by cost-benefit considerations such as those discussed in Section 2 . More specifically, they enable us to investigate how employers' willingness to invest in temporary workers depends on aspects that are related to the expected costs and benefits of training.

Employers who invest in transferable skills could face hold-up problems or employee poaching. Hence, employers might be more willing to invest in training related to firm-specific skills that bind employees to the organisation, instead of investing in skills with a more transferable (or general) character (Becker, 1975).

A financial contribution ensures that part of the training costs are immediately covered, lowering the direct costs of training for the employer in a predictable way. ${ }^{10}$ The risk of employees potentially leaving the organisation shortly after the training ends - in which case the employer will not be able to reap the full benefits of the training and might not even be able to earn back its initial costs - is addressed by the repayment agreement. We designed a one-year repayment agreement because a repayment agreement is intended to recover the costs of training in the event the worker voluntarily leaves ${ }^{11}$ the organisation before the end of the contract and temporary contracts have a duration of two years in our experiment. In addition, since the training budget in our experiment is not excessively large $(€ 2,000)$, a repayment agreement stretching over several years does not seem necessary and could be considered less reasonable from the employee's perspective.

Discrete choice experiments have some advantages over revealed preference data and traditional survey questions. First, discrete choice experiments are well suited for analysing multidimensional decision making, since the effects of multiple aspects of a decision can be distinguished by including multiple attributes. Since the effects of these attributes are measured in terms of a single behavioural outcome variable - in our case, a dummy variable indicating which worker has been selected for the training - it is possible to measure the relative importance of these attributes and evaluate their tradeoffs. Second, since the training attributes are varied exogenously and the respondents are being explicitly told that other, unlisted characteristics are in all cases identical, causal effects can, in principle, be identified (Hainmueller, 2014). ${ }^{12}$ Third, revealed preference data describe actual choices

10. In the experiment, financial contributions are listed separately from the cost of the training. This prevents respondents from using variations in these training costs that could affect the quality or content of the training.

11. The repayment agreement in our experiment only applies when the worker leaves the organisation voluntarily, since the agreement is meant to remove (part) of the risk of a worker unexpectedly leaving the organisation. Moreover, in the Netherlands, employers are not allowed to invoke a repayment agreement (studiekostenbeding) if they take the initiative to terminate the employment relationship themselves (Zekic, 2010).

12. However, a possible caveat could be that the respondents are not answering fully in accordance with the notion that unlisted characteristics are in all cases identical. This can happen when specific characteristics of the permanent and temporary staff in their own organisations are being implicitly taken into account. In such a case, omitted variable bias can arise as employers' evaluations of the included attributes are 
and are therefore restricted to the set of currently available options, whereas, in discrete choice experiments, hypothetical alternatives can be included that are not (yet) part of the current choice set (Hensher \& Bradley, 1993). Hence, these experiments also open up the opportunity to evaluate trade-offs for which no real-world data yet exist. For example, when repayment agreements are not very common ${ }^{13}$ or when there are legal or regulatory barriers to their implementation, a stated choice experiment helps to quantify the effects of such agreements on the supply of training courses without the presence of any obstacles. Fourth, discrete choice experiments enable us to observe all available combinations of attributes, as well as options that are not chosen, which is rarely the case when using revealed preference data. Finally, social desirability bias is limited compared to direct survey questions, since the respondents are probably not fully aware of the reason for the experimental manipulation (Alexander \& Becker, 1978; Wallander, 2009) and because the profiles provide respondents with multiple reasons to justify any particular choice (Hainmueller, 2014).

The advantages associated with discrete choice experiments also come with a potential cost. A discrete choice experiment, by definition, relates to hypothetical choices instead of actual behaviour. However, studies have shown a high level of consistency between choices made in discrete choice experiments, on the one hand, and actual behaviour and choices made in field experiments, on the other (Ganong \& Coleman, 2006; Hainmueller et al., 2015; Henkens, Van Solinge, \& Cozijnsen, 2009; Karpinska, Henkens, \& Schippers, 2011; Telser \& Zweifel, 2007). Moreover, we have presented employers with a hypothetical scenario that is as realistic as possible. We have done this by keeping the direct costs of training and the number of hours it takes to finish a course realistic within the Dutch setting (Fouarge, Van Eldert, De Grip, Künn, \& Poulissen, 2018; Statistics Netherlands, 2017) and by keeping the decision tasks clear, manageable, and easy, which we have accomplished by limiting the number of attributes and attribute values.

\section{Empirical strategy}

We estimate mixed logit models to relate employers' willingness to invest to the attributes included in our experiment. Contrary to alternatives such as conditional logit models, mixed logit models do not assume the error terms to be independent across alternatives and therefore do not assume the independence of irrelevant alternatives (IIA; see Hensher \& Greene, 2003; Train, 2003). In our context, this is a significant advantage, since the IIA assumption would, for example, assume that the probability of employers choosing permanent workers over temporary workers without prospects does not change when a third option, temporary workers with prospects, is added to the choice set. This assumption would be violated if employers considered some contract types to be very similar to one another, while others are considered to be very dissimilar. The literature has shown that permanent and temporary workers with prospects are very similar in terms of actual training participation and provision, whereas there is a major difference between temporary workers with and without prospects (Ferreira et al., 2017; Fouarge et al., 2012). This finding suggests that employers could treat temporary workers with prospects more as permanent workers than as temporary workers

'contaminated' by the (perceived) relationship with omitted attributes (Lancsar, Fiebig, \& Hole, 2017). We address this issue in our robustness checks.

13. While repayment agreements are already quite common in some Anglo-Saxon countries such as the United Kingdom (Story \& Redman, 1997) and the United States (Long, 2004; Von Bergen, Mawer, \& Journal, 2007), they are not (yet) common practice in the Netherlands (Scheele, Theeuwes, \& De Vries, 2007). 
without prospects, which would indeed violate the IIA assumption. ${ }^{14}$ An additional advantage of mixed logit models is that they do not assume that every employer has exactly the same preferences: the model allows coefficients to vary across employers (Layton, 2000).

We start our empirical analysis with the estimation of a mixed logit model in which employer i's choice of whether to offer the training to employee $j$ in choice task $v$ is regressed on the values taken by the attributes in the experiment:

$$
\text { choice }_{\mathrm{ijv}}=\beta_{i j v}^{1} c_{i j v}+\beta_{i j v}^{2} s_{i j v}+\beta_{i j v}^{3} f_{i j v}+\beta_{i j v}^{4} a_{i j v}
$$

where $c$ represents the contract type, $s$ the specificity of the training, $f$ the financial contribution made by the employee, and $a$ the repayment agreement that applies for this specific profile.

Subsequently, we analyse whether the impact of these attributes differs by the type of contract. To this end, we re-estimate our basic model by sequentially including interaction terms between the contract type and 1 ) the specificity of the training offered $\left.\left(\beta_{i j t} c_{i j t} * s_{i j t}\right), 2\right)$ the financial contributions workers are making $\left(\beta_{i j t} c_{i j t} * f_{i j t}\right)$, and 3 ) the repayment agreement that applies if the worker voluntarily leaves the organisation within one year after the training ends $\left(\beta_{i j t} c_{i j t} * a_{i j t}\right)$.

In all of our models, we estimate cluster-robust standard errors to allow for intragroup correlation, since we have multiple decision rounds per participant (Huber, 1967).

\section{Results}

\section{Employers' willingness to invest in training}

The first model in Table 3 shows our baseline results, in which employers' willingness to invest in training is regressed on the attributes included in our experiment. The estimation results show that all attributes have a significant impact on employers' willingness to invest. The fact that the standard deviations of the random coefficients are also significant in many cases indeed shows preference heterogeneity among respondents.

$<$ Insert Table 3 here $>$

Both the mean coefficients and the standard deviations of the random coefficients in Table 3 should be interpreted in terms of log odds and can be exponentiated to obtain odds ratios. For ease of interpretation, Figure 1 graphically represents the corresponding average marginal effects.

$<$ Insert Figure 1 here $>$

14. We also performed Hausman tests where we partition the choice set into a complete, unrestricted set containing all three types of contracts and some restricted sets where we always exclude one type of contract. We then tested whether the estimated coefficients from the restricted and unrestricted sets were sufficiently similar. Given these tests, the IIA assumption was indeed rejected. 


\section{Contract types}

The average marginal effects in Figure 1 show a large gap in employers' willingness to invest between temporary and permanent workers. Employers are almost 10 percentage points less likely to invest in temporary workers who have prospects of a permanent contract, compared to workers who already have a permanent contract. Employers exhibit even less willingness to invest in temporary workers who do not have prospects of obtaining a permanent contract, where the difference with permanent workers is equal to 35.4 percentage points. This result suggests that employers treat temporary workers with prospects more like permanent workers and less like their temporary colleagues without prospects. This finding is in line with research showing that the actual level of training participation of temporary workers with prospects of a permanent contract is closer to the level of workers with a permanent contract than to that of temporary workers without prospects (Ferreira et al., 2017; Fouarge et al., 2012).

\section{Responsiveness to training investment characteristics related to the costs and benefits of training}

Consistent with the theoretical literature on firm-specific versus general training (Becker, 1975), Figure 1 shows that employers prefer investing in firm-specific training. Compared to investing in transferable training that is not only applicable within their own organisation, but also in organisations operating in the same sector of industry, employers are three percentage points more willing to invest in firm-specific training. Surprisingly, the willingness to invest in training that is not only applicable within one's own organisation and sector of industry, but also in other sectors of industry, does not differ significantly from the willingness to invest in industry-specific training. This result suggests that employers are reluctant to invest in transferable skills per se, while the degree of transferability does not seem to matter. This reluctance, however, is much less than their reluctance to offer training to workers on temporary contracts (both without and, to a lesser extent, with prospects of a permanent contract).

Employers' willingness to offer training also depends on the existence and size of the worker's financial contribution and applicable repayment agreement. However, we observe diminishing returns with respect to these variables (Figure 1). A contribution of $€ 200$ increases the willingness to invest by 7.5 percentage points compared to no financial contribution, while doubling the financial contribution from $€ 200$ to $€ 400$ has little added value, since it increases the willingness to train by only two percentage points. Introducing a repayment agreement equal to $50 \%$ of total training costs increases the willingness to invest by 15 percentage points, while a repayment that is twice as strict increases the willingness to invest by an additional 10 percentage points. The fact that a repayment agreement has a strong positive effect on the willingness to train suggests that employers are indeed concerned that employees might leave the organisation before being able to earn back the initial training investment. 


\section{Compensatory mechanisms}

The fact that employers are responsive to training investment characteristics such as the financial contributions of employees and repayment agreements suggest that these could be used as an effective compensatory mechanism to increase the willingness to invest in temporary workers.

\section{Compensatory impact of a financial contribution}

Figure 1 shows that the effect of a $€ 400$ financial contribution on employers' willingness to invest is approximately the same size in absolute terms as the effect of an employee having a temporary contract with prospects. This result suggests that a financial contribution could act as a compensatory mechanism for employers' lower willingness to invest in temporary workers. Panel A of Figure 2 therefore shows the trade-off between employees' contract type and their financial contribution in determining employers' willingness to invest. The graph is based on a regression where we add interaction terms between the contract type and the financial contribution an employee is willing to make (Model (3) in Table 3). The vertical axis represents employers' willingness to invest (by showing the probability of an employer selecting a given employee), while the three types of contracts are distinguished on the horizontal axis. The three lines each represent a certain level of financial contribution. All three lines are downward sloping, which means that, with a certain financial contribution, employers are always less willing to invest in an employee with a less certain employment contract. For each type of contract, employers' willingness to invest also increases when workers contribute to the cost of the training. However, the additional increase in the willingness to invest if one is willing to contribute $€ 400$ instead of $€ 200$ is only significant for workers with a temporary contract who have prospects of obtaining a permanent contract (see Model (3) in Table 3). Even though this result implies some difference in the degree to which these characteristics affect employers' willingness to invest in temporary versus permanent workers, a substantial improvement in the relative willingness to invest in temporary workers can only be achieved when temporary workers make a larger financial contribution compared to permanent workers.

As can be seen from Panel A in Figure 2, the gap in employers' willingness to invest between temporary workers with prospects and those with a permanent contract can be closed when the former are contributing financially and the latter are not. When a worker with a temporary contract with prospects contributes $€ 200$, the point estimate of employers' willingness to invest is close to the point estimate for their willingness to invest in a permanent employee who does not contribute financially ( $57.8 \%$ versus $60.9 \%$, respectively, the difference not being statistically significant). Contributing $€ 400$ even increases the probability of an employer offering training to a temporary worker to $63.3 \%$, although this result is still not significantly larger than the probability of the employer choosing a permanent worker who does not contribute financially. We therefore conclude that a financial contribution made by temporary workers with prospects can be used to close the gap in employers' willingness to invest between these workers and permanent workers.

Irrespective of the financial contribution made by the employee, employers' willingness to invest in temporary workers without any prospects of a permanent contract is always lower compared to their willingness to invest in permanent workers or in temporary workers with prospects. Even when temporary workers without prospects are contributing the maximum amount possible in our study (€400) while permanent workers or temporary workers with prospects are not contributing financially, employers' willingness to invest in these workers with a more certain employment contract is still 
significantly higher $(60.9 \%$ and $48.2 \%$, respectively, versus $32.2 \%$ for temporary workers without prospects). Since doubling the financial contribution from $€ 200$ to $€ 400$ has no additional positive impact on the willingness to invest in temporary workers without prospects, an even larger financial contribution than the maximum of $€ 400$ is highly unlikely to change our conclusion that employers prefer to invest in permanent workers or workers who have prospects of a permanent contract, irrespective of the employee's financial contribution. We therefore conclude that, while a financial contribution can be used to increase the willingness to invest in temporary employees without prospects, it cannot be used to fully compensate employers' preference to invest in employees with such prospects or who already have a permanent contract.

\section{$<$ Insert Figure 2 here $>$}

\section{Compensatory impact of a repayment agreement}

Figure 1 also shows that the effect of a 100\% repayment agreement is over two and a half times, in absolute terms, as big as the effect of having a temporary contract with prospects. This result suggests that a repayment agreement could be an effective compensatory mechanism for employers' lower willingness to invest in temporary workers. Panel B of Figure 2 shows the trade-off between the employee's contract type and the repayment agreement with respect to employers' willingness to invest in training. The graph is based on Model (4) in Table 2. Again, all three lines have a downward slope; that is, given a specific type of repayment agreement, employers are less willing to invest in workers with a more uncertain employment contract. The lines also never cross or touch, which implies that, for each type of contract, employers' willingness to invest increases when implementing a (stricter) repayment agreement. Since we do not find a statistically significant interaction effect between the type of contract and the repayment agreement, there is no evidence of a difference in the degree to which these characteristics affect employers' willingness to invest in temporary versus permanent workers. Nevertheless, a repayment agreement can still be used to increase employers' willingness to invest in temporary workers. First, such agreements can be altered to increase the willingness to invest in temporary workers in an absolute sense. Second, implementing a repayment agreement for temporary workers only - or to a larger extent - will substantially increase the willingness to invest in temporary versus permanent workers.

As the predicted probabilities in Panel B of Figure 2 show, employers are more likely to select a temporary employee who has prospects of a permanent contract with a $50 \%$ repayment agreement than a permanent worker without a repayment agreement (with predicted margins of $57.8 \%$ versus $51.2 \%$, respectively). Moreover, a full repayment agreement implemented for temporary workers with prospects would even result in employers being indifferent between investing in these temporary workers versus permanent workers with a $50 \%$ repayment agreement (with predicted margins of $69 \%$ versus $67.7 \%$, respectively). Hence, a repayment agreement can be considered an effective mechanism to improve employers' willingness to invest in temporary workers with prospects and can be used as a compensatory mechanism to fully close the gap in employers' willingness to invest in the latter or even result in employers clearly preferring to invest in a temporary worker with prospects instead of a permanent worker. 
While employers' willingness to invest in temporary workers without prospects can also be significantly increased by implementing a repayment agreement, our results show that it is impossible for a repayment agreement to fully close the gap in employers' willingness between investing in these workers and investing in employees with permanent contracts. Even when a full repayment agreement is introduced for this group of temporary workers, the willingness to invest in them is still significantly lower $(41.7 \%)$ compared to the willingness to invest in permanent workers without a repayment agreement (51.2\%). However, when those without prospects have a full repayment agreement, employers' willingness to invest in them equals their willingness to invest in temporary workers with prospects and no repayment agreement: the point estimates are quite similar and not statistically different from each other ( $41.7 \%$ and $41.9 \%$, respectively). A full repayment agreement can therefore be used to close the gap between employers' willingness to invest in temporary workers without prospects and those with prospects, but not the gap between temporary workers without prospects and permanent workers.

\section{Compensatory impact of combining a financial contribution with a repayment agreement}

Table 4 shows employer preferences when a financial contribution is combined with a repayment agreement. The results are based on a regression that includes interaction terms of the financial contribution and the repayment agreement with the type of contract (see Model (6), Table 3). Since we have shown that a financial contribution or a repayment agreement on its own cannot fully close the gap in employers' willingness to invest between a temporary worker without prospects and a permanent worker, we focus on the comparison between these types of contracts. ${ }^{15}$

$<$ Insert Table 4 here $>$

When temporary employees without prospects are both contributing financially and have a repayment agreement for the remaining training costs, there is no statistically significant difference in employers' willingness to invest between these temporary employees without prospects and a permanent worker who does not contribute financially and does not have a repayment agreement (43.3\% when contributing $€ 200$ or $43.3 \%$ when contributing $€ 400$ for temporary workers, versus $46 \%$ for the permanent worker). We therefore conclude that the gap in employers' willingness to invest between a temporary worker without prospects and a permanent worker can be fully closed when a full repayment agreement is combined with a financial contribution to the costs of the training.

\section{Robustness checks}

Robustness of employers' lower willingness to invest in temporary workers

Our discrete choice experiment estimation results show that employers are much less willing to invest in temporary workers than in permanent workers (Table 3, Model (1)). In Table 5, we perform various robustness checks to this effect.

15. We also conclude that a financial contribution by a temporary worker without prospects would not be able to increase employers' willingness to invest in this worker to a level equal to or close to their willingness to invest in a permanent worker. However, since a repayment agreement appears to be able to bridge this gap on its own, it is no longer strictly necessary to combine it with a financial contribution to close the gap. 
First, we consider the fact that some employers in our survey have no or only limited experience with employing temporary workers. ${ }^{16}$ It could be difficult for them to make well-informed decisions. Therefore, we estimate our baseline regression again for a subsample of employers who employed people in all three contract categories (Model (1) of Table 5). The estimation results show that, even when restricting our sample to these employers, they are still less willing to invest in temporary workers, with the most pronounced effect for temporary workers without prospects of a permanent contract. Employers' lower willingness to invest in temporary workers is therefore not driven by organisations with no or only a limited experience with temporary workers.

Second, even though we explicitly instructed employers that the employees in our experiment only differ in the set of attributes we show them, they can still have implicit ideas about temporary workers, which could influence their evaluation of the type of contract (Lancsar et al., 2017). ${ }^{17}$ Perhaps they implicitly argue that temporary workers, especially those without prospects, have a temporary contract for a reason, for example, because they are less productive in their job or less motivated to learn, which could decrease the return from a training investment in them. This is why we asked employers to rate the average ability and motivation of workers in each of the three contract categories after conducting the experiment (see Appendix B, Table B1). The answers to the survey question reveal that employers believe temporary workers without prospects are both less able and less motivated to learn compared to permanent workers or temporary workers who do have prospects of a permanent contract (see Appendix B, Table B2). This raises the question of whether the lack of willingness to invest in temporary workers without prospects is (partly) driven by these lower assessments of these workers. To test this, Model (2) of Table 5 includes an interaction term between employers' perceptions and the contract type. ${ }^{18}$ We find no significant interaction effects. The fact that there are substantial differences in employers' perceptions regarding the learning ability and motivation of workers with different types of contracts but that these differences do not influence their willingness to invest in temporary workers in our experiment suggests that our instruction that workers differ only in the attributes mentioned was internalised by the respondents.

Third, since the employers in our experiment were forced to choose an employee to offer training (a no-choice alternative was not possible), we also checked whether our results would overestimate the willingness to invest in temporary workers. We therefore exclude choice sets where the respondents are forced to choose between temporary workers. In Model (3), we therefore estimate our baseline model again, but now without including the choice sets in which the hypothetical employees had the same type of temporary contract. In Model (4) we do the same, but also excluding the choice sets in which the respondents are forced to choose between two different types of temporary contracts. The estimation results show that our findings with respect to employers' willingness to invest in temporary workers are robust to these exclusions.

16. We instructed employers who did not employ temporary workers to imagine how they would choose if they did employ these workers (see Appendix A).

17. These implicit ideas about temporary workers are part of the perceptions mentioned at the beginning of Section 2 that co-determine the choices employers make.

18. We consider an employer to have a negative perception about either the ability or the motivation to learn (or both) if the employer rates at least one of the two temporary workers lower than the permanent workers in this variable (or both variables). 
Finally, due to the orthogonal design of our experiment, some choice sets could include profiles in which one profile is superior to the other in all attributes. Model (5) of Table 5 shows the estimation results of a robustness check in which we exclude choice sets in which the temporary worker's profile is clearly dominated by the permanent worker's, to check whether this leads to an overestimation of the gap in employers' willingness to invest between permanent and temporary workers. More specifically, we exclude choice sets in which the permanent worker contributes the maximum amount in our experiment (€400) and is subject to the strictest repayment agreement (100\%) while the temporary worker does not contribute financially $(€ 0)$ and is not subject to a repayment agreement $(0 \%)$. In these cases, it would probably make little sense for employers to pick the temporary worker. Again, the results corroborate our findings with respect to employers' willingness to invest in temporary workers.

\section{Robustness to the estimation technique}

Finally, Table 6 presents a robustness check to investigate the stability and robustness of our baseline results, including the interaction terms between the attributes (see Table 3, Models (5) and (6)), to different estimation techniques (Hensher \& Greene, 2003; Lancsar et al., 2017). Column (1) of Table 6 shows the estimation results from a linear probability model, Column (2) the results from a logit estimation, and Column (3) the results from a conditional logit model. Column (4) shows the results of a fixed effects model, and Column (5) the results of a random effects model.

$<$ Insert Table 6 here $>$

Table 6 shows that the estimation results of all the models are very close to the results of the mixed logit estimations presented in Table 2 and Figure $1 .{ }^{19}$ This shows that our findings are robust to different estimation techniques.

\section{Conclusion}

In this paper, we develop a theoretical framework to explain employers' provision of training to workers with different employment contracts and test its implications using a discrete choice experiment. Our theoretical framework predicts not only that employers are less willing to invest in temporary workers, but also that employers' willingness to offer training depends on characteristics that are related to the costs and benefits associated with training.

Our discrete choice experiment measures employers' willingness to invest in employees with different types of contracts under varying, controlled conditions. With respect to the contract type, we distinguish between workers with a permanent contract and two types of temporary workers: those who have prospects of a permanent contract at their current organisation and those who do not. The experiment enables us to check whether employers are indeed less willing to invest in temporary workers, as predicted by our theoretical framework. Moreover, we use exogenous variation in the characteristics of the training investment to investigate to what extent employers' willingness to

19. The coefficients of the logit and conditional logit models cannot be compared directly to the coefficients from the other models. However, we also calculate the average marginal effects for these models and the magnitudes of the effects are comparable to those of the other models (results available upon request). 
invest in temporary workers depends on training investment characteristics that affect the costbenefit assessment of the training investment. More specifically, we look at the content of the training (firm-specific versus transferable training), the financial contribution made by the employee to cover part of the training costs, and any repayment agreement that applies if the employee leaves the organization shortly after the training ends.

Our results show a large and significant gap in employers' willingness to invest between temporary and permanent workers. For temporary workers with prospects of a permanent contract, the gap is equal to almost 10 percentage points, whereas this gap is 36 percentage points for temporary workers without prospects of a permanent contract. From the perspective of the employee, this result implies that the penalty of having a temporary contract for those without prospects of a permanent contract is almost four times the penalty for temporary workers who do have prospects of a permanent contract. This finding also suggests that employers treat temporary workers with prospects of a permanent contract more as permanent workers than as temporary workers who do not have such prospects. Our results, therefore, seem to explain not only why temporary workers train less, but also why the difference in actual training participation between the two types of temporary workers is often greater than the difference between permanent workers and temporary workers with prospects of a permanent contract (Ferreira et al., 2017; Fouarge et al., 2012).

The lower willingness to invest in temporary workers suggests that employers are underinvesting in the human capital development of temporary workers. This finding could reinforce existing labour market segmentation and result in temporary employees being at risk of becoming stuck in temporary jobs because they are falling behind in a rapidly changing labour market where skills depreciate quickly. A temporary job could therefore become a dead end instead of a stepping stone to permanent work (Booth et al., 2002).

We also show that employers' willingness to invest in temporary workers depends on training investment characteristics that are related to the cost-benefit assessment behind employers' training decisions. First, employers are more likely to invest in temporary workers when the expected benefits from training are greater because the training enables workers to acquire firm-specific instead of transferable skills. However, transferable skills are exactly the type of skill that temporary workers need when their contract with their current employer expires. Employers' lower willingness to invest in transferable skills could therefore be seen as an additional disadvantage for temporary workers who want to increase their external employability. Second, a repayment agreement also increases employers' willingness to invest in temporary workers by reducing (part of) the costs if the trained worker quits prematurely and by increasing the expected benefits from training by broadening the investment horizon at the same time. Finally, decreasing the expected cost of training by a financial contribution to the training costs of the employees also increases employers' willingness to invest.

The fact that employers can influence training investment characteristics such as the transferability of the training, employees' financial contributions, and repayment agreements suggests that firms' human resource development practices can be used to reduce the gap between employers' willingness to invest in temporary and permanent employees. However, we find an almost similar impact of these three cost-benefit-related training investment characteristics on employers' willingness to invest in permanent workers. For example, employers prefer to invest in firm-specific human capital to the same degree for every type of contract. Changing one or more of these training 
investment characteristics in the same way for both types of workers will therefore increase the willingness to invest in both temporary and permanent workers, but it will not change employers' relative preference to invest in permanent workers. Nonetheless, since financial contributions, repayment agreements, and firm-specific training will lower the costs and increase firms' benefits of training, more employees could be trained using the same budget. Hence, under stable relative preferences, this approach could also increase the number of temporary workers receiving training, although the gap between training offers to temporary and permanent workers will then remain equally large. However, this gap is likely to decrease once these training investment characteristics are changed only for temporary workers and not (or to a lesser extent) for permanent workers. In this case, employers' willingness to invest in temporary workers will increase, and employers' relative preference to invest in permanent workers will decrease, narrowing the gap. If temporary workers are subject to a full repayment agreement and are making a large financial contribution while permanent workers are not subject to such a repayment agreement and not contributing financially, the gap in employers' willingness to invest in training is likely to disappear completely, even for temporary workers who have no prospects of a permanent contract.

As postulated in our theoretical framework, not only the cost-benefit-related characteristics of the training investment influence employers' willingness to invest in temporary versus permanent workers: employer characteristics can also determine the relative preference for temporary workers. We have also noted that the standard deviation of the random coefficients in our mixed logit estimations are significant in many cases. This result hints at preference heterogeneity among employers when it comes to the willingness to invest in temporary workers. This finding could be related to the industry sector and the share of temporary workers in total employment in the sector or firm. While we did not focus on the structure of this preference heterogeneity in this paper, we performed robustness analyses to check whether the gap in employers' willingness to invest between permanent and temporary workers is driven by employers with limited experience with temporary workers or by their negative perceptions regarding the abilities and training motivation of temporary workers. However, our results show that the significantly lower willingness of firms to train temporary workers persists, even after taking these factors into account. 


\section{References}

Albert, C., García-Serrano, C., \& Hernanz, V. (2005). Firm-provided training and temporary contracts. Spanish Economic Review, 7(1), 67-88.

Alexander, C. S., \& Becker, H. J. (1978). The use of vignettes in survey research. Public opinion quarterly, 42(1), 93-104.

Arulampalam, W., \& Booth, A. L. (1998). Training and labour market flexibility: Is there a trade-off? British Journal of Industrial Relations, 36(4), 521-536.

Autor, D. H. (2001). Why do temporary help firms provide free general skills training? Quarterly Journal of Economics, 116(4), 1409-1448.

Barron, J. M., \& Berger, M. C. (1999). Do workers pay for on-the-job training? Journal of Human Resources, 34(2), 235-252.

Becker, G. (1975). Human Capital: A Theoretical and Empirical Analysis, with Special Reference to Education, 2nd edition. New York: National Bureau of Economic Research.

Benjamin, D. J., Heffetz, O., Kimball, M. S., \& Szembrot, N. (2014). Beyond happiness and satisfaction: Toward well-being indices based on stated preference. American Economic Review, 104(9), 2698-2735.

Booth, A. L., Francesconi, M., \& Frank, J. (2002). Temporary jobs: Stepping stones or dead ends? Economic Journal, 112(480), F189-F213.

Booth, A. L., \& Zoega, G. (2000). Why do firms invest in general training? 'Good' firms and 'bad' firms as a source of monopsony power. CEPR Discussion Paper, No 2536.

Borghans, L., Romans, M., \& Sauermann, J. (2010). What makes a good conference? Analysing the preferences of labour economists. Labour Economics, 17(5), 868-874.

Crawford, V. P. (1988). Long-term relationships governed by short-term contracts. The American Economic Review, 78(3), 485-499.

Crawford, V. P. (1990). Relationship-specific investment. Quarterly Journal of Economics, 105(2), 561-574.

De Grip, A., Van Loo, J., \& Sanders, J. (2004). The industry employability index: Taking account of supply and demand characteristics. International Labour Review, 143, 211.

Ferreira, M., De Grip, A., \& Van der Velden, R. (2018). Does informal learning at work differ between temporary and permanent workers? Evidence from 20 OECD countries. Labour Economics, $55,18-40$.

Ferreira, M., Künn, A., \& De Grip, A. (2017). Work-related learning and skill development in Europe: Does initial skill mismatch matter? Research in Labor Economics, 45, 345-407.

Finegold, D., Levenson, A., \& Van Buren, M. (2005). Access to training and its impact on temporary workers. Human Resource Management Journal, 15(2), 66-85.

Forrier, A., \& Sels, L. (2003). Temporary employment and employability: Training opportunities and efforts of temporary and permanent employees in Belgium. Work, Employment and Society, 17(4), 641-666.

Fouarge, D., De Grip, A., Smits, W., \& De Vries, R. (2012). Flexible contracts and human capital investments. De Economist, 160(2), 177-195.

Fouarge, D., Van Eldert, P., De Grip, A., Künn, A., \& Poulissen, D. (2018). Nederland in leerstand. ROA Reports, No. 004.

Ganong, L. H., \& Coleman, M. (2006). Multiple segment factorial vignette designs. Journal of Marriage and Family, 68(2), 455-468.

Hainmueller, J. (2014). Causal inference in conjoint analysis: Understanding multidimensional choices via stated preference experiments. Political Analysis, 22(1), 1.

Hainmueller, J., Hangartner, D., \& Yamamoto, T. (2015). Validating vignette and conjoint survey experiments against real-world behavior. Proceedings of the National Academy of Sciences, $112(8), 2395-2400$. 
Henkens, K., Van Solinge, H., \& Cozijnsen, R. (2009). Let go or retain? A comparative study of the attitudes of business students and managers about the retirement of older workers. Journal of Applied Social Psychology, 39(7), 1562-1588.

Hensher, D. A., \& Bradley, M. (1993). Using stated response choice data to enrich revealed preference discrete choice models. Marketing Letters, 4(2), 139-151.

Hensher, D. A., \& Greene, W. H. (2003). The mixed logit model: The state of practice. Transportation, 30(2), 133-176.

Huber, P. J. (1967). The behavior of maximum likelihood estimates under nonstandard conditions. Berkeley Symposium on Mathematical Statistics and Probability, 1(1), 221.

International Labour Organization, Organisation for Economic Co-operation and Development, \& World Bank. (2016). Enhancing employability: Report prepared for the G20 Employment Working Group with inputs from the International Monetary Fund. Paris: OECD.

Jonker, N., \& De Grip, A. (1999). Do employees with flexible contracts receive less training? ROA Research Memoranda, ROA-RM-1999/1E. Maastricht University, Research Centre for Education and the Labour Market.

Karpinska, K., Henkens, K., \& Schippers, J. (2011). The recruitment of early retirees: A vignette study of the factors that affect managers' decisions. Ageing and Society, 31(4), 570-589.

Kristensen, N., \& Johansson, E. (2008). New evidence on cross-country differences in job satisfaction using anchoring vignettes. Labour Economics, 15(1), 96-117.

Lancsar, E., Fiebig, D. G., \& Hole, A. R. (2017). Discrete choice experiments: A guide to model specification, estimation and software. PharmacoEconomics, 35(7), 697-716.

Layton, D. F. (2000). Random coefficient models for stated preference surveys. Journal of Environmental Economics and Management, 40(1), 21-36.

Lazear, E. P. (2009). Firm-specific human capital: A skill-weights approach. Journal of Political Economy, 117(5), 914-940.

Loewenstein, M. A., \& Spletzer, J. R. (1997). Delayed formal on-the-job training. Industrial and Labor Relations Review, 51(1), 82-99.

Long, B. S. (2004). Protecting employer investment in training: Noncompetes vs. repayment agreements. Duke Law Journal, 54, 1295.

Malhotra, N. K. (1982). Information load and consumer decision making. Journal of Consumer Research, 8(4), 419.

McFadden, D. L., Bemmaor, A. C., Caro, F. G., Dominitz, J., Jun, B.-H., Lewbel, A., ... Winter, J. K. (2005). Statistical analysis of choice experiments and surveys. Marketing Letters, 16(3), 183196.

Mincer, J. (1962). On-the-job training: Costs, returns, and some implications. Journal of Political Economy, 70(5, Part 2), 50-79.

Oosterbeek, H. (1996). A decomposition of training probabilities. Applied Economics, 28(7), 799-805.

Rao, V. R. (2014). Applied Conjoint Analysis. Berlin: Springer.

Sauermann, J. (2006). Who Invests in Training if Contracts are Temporary? Empirical Evidence for Germany Using Selection Correction. IWH Discussion Papers, No. 14.

Scheele, D., Theeuwes, J. J. M., \& De Vries, G. J. M. (2007). Arbeidsflexibiliteit en onts/agrecht. Amasterdam: Amsterdam University Press.

Sieben, I. (2007). Does training trigger turnover - or not? The impact of formal training on graduates' job search behaviour. Work, Employment and Society, 21(3), 397-416.

Statistics Netherlands. (2017). Meer bedrijven met bedrijfsopleidingen. Retrieved from https://www.cbs.nl/nl-nl/nieuws/2017/28/meer-bedrijven-met-bedrijfsopleidingen

Statistics Netherlands. (2019). Werkzame beroepsbevolking; anciënniteit. Retrieved from: https://opendata.cbs.nl/statline/\#/CBS/nl/dataset/82916NED/table?dl=2C834

Stevens, M. (2001). Should firms be required to pay for vocational training? The Economic Journal, 111(473), 485-505. 
Story, A., \& Redman, T. (1997). Training agreements: Resolving under-investment in training? International Journal of Training and Development, 1(3), 144-147.

Telser, H., \& Zweifel, P. (2007). Validity of discrete-choice experiments evidence for health risk reduction. Applied Economics, 39(1), 69-78.

Train, K. (2003). Discrete choice methods with simulation. Cambridge: Cambridge University Press.

Van Soest, A., \& Vonkova, H. (2014). How sensitive are retirement decisions to financial incentives? A stated preference analysis. Journal of Applied Econometrics, 29(2), 246-264.

Verlegh, P. W. J., Schifferstein, H. N. J., \& Wittink, D. R. (2002). Range and number-of-levels effects in derived and stated measures of attribute importance. Marketing Letters, 13(1), 41-52.

Von Bergen, C. W., Mawer, W. T., \& Journal, R. (2007). Recouping training and development costs using preemployment agreements. Employee Responsibilities and Rights Journal, 19(2), 127143.

Wallander, L. (2009). 25 years of factorial surveys in sociology: A review. Social Science Research, 38(3), 505-520.

Welch, F., \& Ureta, M. (2002). The obsolescence of skill. Research in Labor Economics, 21, 51-81.

Wiswall, M., \& Zafar, B. (2018). Preference for the workplace, investment in human capital, and gender. Quarterly Journal of Economics, 133(1), 457-507.

Zekic, N. (2010). Het studiekostenbeding: Tijd voor een wettelijke regeling. Tijdschrift recht en arbeid, 2(4), 5-10. 
Table 1: Distribution of responses by industry sector and size

\begin{tabular}{|c|c|c|}
\hline & Sample $_{1}(\%)$ & Population $_{2}(\%)$ \\
\hline \multicolumn{3}{|l|}{ Sector } \\
\hline Agriculture, forestry, and fishing & 1.5 & 4.2 \\
\hline $\begin{array}{l}\text { Industry (including mineral extraction and } \\
\text { energy) }\end{array}$ & 11.9 & 10.7 \\
\hline Building industry & 9.1 & 7.4 \\
\hline Trade & 20.1 & 23.4 \\
\hline Transport & 5.6 & 4.6 \\
\hline Hotel and catering sector & 3.7 & 9.3 \\
\hline Business services & 23.1 & 24 \\
\hline Non-profit & 17 & 10.9 \\
\hline Culture, recreation, and other services & 8.1 & 5.4 \\
\hline \multicolumn{3}{|l|}{ Size } \\
\hline 5-9 employees & 34.9 & 49.1 \\
\hline 10-19 employees & 21.5 & 24.8 \\
\hline 20-49 employees & 20.4 & 15 \\
\hline 50-99 employees & 9.9 & 5.3 \\
\hline 100 or more employees & 13.3 & 5.9 \\
\hline $\begin{array}{l}{ }_{1} \text { Source: } 2017 \text { Employer Training Policy S } \\
{ }_{2} \text { Source: Statistics Netherlands } 2017\end{array}$ & & \\
\hline
\end{tabular}


Table 2: Attributes and attribute values

\begin{tabular}{|c|c|}
\hline Attributes & Levels \\
\hline Contract type & $\begin{array}{l}\text { Permanent } \\
\text { Temporary for } 2 \text { years with prospects of a permanent } \\
\text { contract } \\
\text { Temporary for } 2 \text { years without prospects of a } \\
\text { permanent contract }\end{array}$ \\
\hline Applicability of training & $\begin{array}{l}\text { In one's own organisation and other organisations } \\
\text { within and outside one's industry sector } \\
\text { In one's own organisation and other organisations in } \\
\text { one's industry sector } \\
\text { Exclusively in one's own organisation }\end{array}$ \\
\hline Employee financial contribution & $\begin{array}{l}€ 0 \\
€ 200 \\
€ 400\end{array}$ \\
\hline Training cost repayment agreement & $\begin{array}{l}\text { No repayment agreement } \\
\text { Employee must pay back } 50 \% \text { of the training costs if } \\
\text { the employee leaves the organisation within } 1 \text { year } \\
\text { Employee must pay back } 100 \% \text { of the training costs if } \\
\text { the employee leaves the organisation within } 1 \text { year }\end{array}$ \\
\hline
\end{tabular}


Table 3: Employers' willingness to invest, baseline mixed logit results

\begin{tabular}{|c|c|c|c|c|c|c|c|c|c|c|c|c|}
\hline \multirow[b]{2}{*}{ Willingness to invest in training } & \multirow{2}{*}{$\begin{array}{l}(1) \\
\text { Mean } \\
\text { coef. }\end{array}$} & \multicolumn{3}{|c|}{$(2)$} & \multirow{2}{*}{$\begin{array}{l}(3) \\
\text { Mean } \\
\text { coef. }\end{array}$} & \multicolumn{3}{|c|}{$(4)$} & \multicolumn{2}{|l|}{ (5) } & \multicolumn{2}{|l|}{ (6) } \\
\hline & & $\begin{array}{c}\text { SD } \\
\text { Random } \\
\text { coef. }\end{array}$ & $\begin{array}{l}\text { Mean } \\
\text { coef. }\end{array}$ & $\begin{array}{c}\text { SD } \\
\text { Random } \\
\text { coef. }\end{array}$ & & $\begin{array}{c}\text { SD } \\
\text { Random } \\
\text { coef. }\end{array}$ & $\begin{array}{l}\text { Mean } \\
\text { coef. }\end{array}$ & $\begin{array}{c}\text { SD } \\
\text { Random } \\
\text { coef. }\end{array}$ & $\begin{array}{l}\text { Mean } \\
\text { coef. }\end{array}$ & $\begin{array}{c}\text { SD } \\
\text { Random } \\
\text { coef. }\end{array}$ & $\begin{array}{l}\text { Mean } \\
\text { coef. }\end{array}$ & $\begin{array}{c}\text { SD } \\
\text { Random } \\
\text { coef. }\end{array}$ \\
\hline \multicolumn{13}{|l|}{$\begin{array}{l}\text { Contract type } \\
\text { (ref. = permanent) }\end{array}$} \\
\hline Temporary with prospects & $\begin{array}{c}-0.773^{* * *} \\
(0.141)\end{array}$ & $\begin{array}{c}0.780 * * * \\
(0.279)\end{array}$ & $\begin{array}{c}-0.752^{* * *} \\
(0.237)\end{array}$ & $\begin{array}{c}0.899 * * * \\
(0.336)\end{array}$ & $\begin{array}{c}-1.079 * * * \\
(0.216)\end{array}$ & $\begin{array}{c}0.935^{* * *} \\
(0.307)\end{array}$ & $\begin{array}{c}-0.786^{* * *} \\
(0.220)\end{array}$ & $\begin{array}{l}-0.761 \\
(0.529)\end{array}$ & $\begin{array}{l}-1.254^{* * *} \\
(0.419)\end{array}$ & $\begin{array}{c}-1.491 * * * \\
(0.481)\end{array}$ & $\begin{array}{c}-1.169 * * * \\
(0.394)\end{array}$ & $\begin{array}{l}0.888^{*} \\
(0.456)\end{array}$ \\
\hline Temporary without prospects & $\begin{array}{c}-3.807^{* * *} \\
(0.502)\end{array}$ & $\begin{array}{l}2.856 * * * \\
(0.501)\end{array}$ & $\begin{array}{c}-4.300 * * * \\
(0.628)\end{array}$ & $\begin{array}{c}3.174 * * * \\
(0.657)\end{array}$ & $\begin{array}{c}-4.025 * * * \\
(0.587)\end{array}$ & $\begin{array}{c}2.925^{* * *} \\
(0.467)\end{array}$ & $\begin{array}{c}-4.133^{* * *} \\
(0.570)\end{array}$ & $\begin{array}{c}2.952 * * * \\
(0.571)\end{array}$ & $\begin{array}{c}-5.625^{* * *} \\
(1.275)\end{array}$ & $\begin{array}{c}3.809 * * * \\
(1.006)\end{array}$ & $\begin{array}{l}-4.295 * * * \\
(0.797)\end{array}$ & $\begin{array}{c}3.063^{* * *} \\
(0.549)\end{array}$ \\
\hline \multicolumn{13}{|c|}{$\begin{array}{l}\text { Transferability of training } \\
\text { (ref. = in own sector and other sectors) }\end{array}$} \\
\hline In own sector & $\begin{array}{l}-0.0727 \\
(0.108)\end{array}$ & $\begin{array}{c}0.466 \\
(0.495)\end{array}$ & $\begin{array}{c}0.00434 \\
(0.207)\end{array}$ & $\begin{array}{l}-0.591 \\
(0.379)\end{array}$ & $\begin{array}{l}-0.0702 \\
(0.113)\end{array}$ & $\begin{array}{c}0.137 \\
(0.459)\end{array}$ & $\begin{array}{l}-0.0582 \\
(0.117)\end{array}$ & $\begin{array}{l}0.616^{*} \\
(0.329)\end{array}$ & $\begin{array}{l}0.0245 \\
(0.236)\end{array}$ & $\begin{array}{l}-0.377 \\
(1.259)\end{array}$ & $\begin{array}{l}-0.0623 \\
(0.116)\end{array}$ & $\begin{array}{l}-0.328 \\
(1.857)\end{array}$ \\
\hline In own organisation & $\begin{array}{l}0.263^{*} \\
(0.136)\end{array}$ & $\begin{array}{l}1.681^{* * *} \\
(0.296)\end{array}$ & $\begin{array}{c}0.274 \\
(0.235)\end{array}$ & $\begin{array}{c}1.897^{* * *} \\
(0.380)\end{array}$ & $\begin{array}{l}0.285^{*} \\
(0.150)\end{array}$ & $\begin{array}{c}1.831^{* * *} \\
(0.346)\end{array}$ & $\begin{array}{l}0.276 * \\
(0.147)\end{array}$ & $\begin{array}{c}1.793 * * * \\
(0.313)\end{array}$ & $\begin{array}{c}0.351 \\
(0.273)\end{array}$ & $\begin{array}{c}2.465^{* * *} \\
(0.754)\end{array}$ & $\begin{array}{c}0.307 \\
(0.192)\end{array}$ & $\begin{array}{c}1.937^{* * *} \\
(0.521)\end{array}$ \\
\hline \multicolumn{13}{|l|}{$\begin{array}{l}\text { Financial contribution employee } \\
(\text { ref. }=€ 0)\end{array}$} \\
\hline$€ 200$ & $\begin{array}{c}0.665 * * * \\
(0.124)\end{array}$ & $\begin{array}{l}-0.457 \\
(0.322)\end{array}$ & $\begin{array}{c}0.731 * * * \\
(0.139)\end{array}$ & $\begin{array}{l}-0.491 \\
(0.364)\end{array}$ & $\begin{array}{c}0.561^{* * *} \\
(0.202)\end{array}$ & $\begin{array}{c}-0.535^{* *} \\
(0.235)\end{array}$ & $\begin{array}{c}0.706 * * * \\
(0.132)\end{array}$ & $\begin{array}{l}0.0553 \\
(0.508)\end{array}$ & $\begin{array}{c}0.619 * * \\
(0.250)\end{array}$ & $\begin{array}{l}-0.622 \\
(0.452)\end{array}$ & $\begin{array}{l}0.579 * * * \\
(0.210)\end{array}$ & $\begin{array}{l}-0.493 \\
(0.847)\end{array}$ \\
\hline$€ 400$ & $\begin{array}{l}0.888 * * * \\
(0.146)\end{array}$ & $\begin{array}{c}1.150 * * * \\
(0.338)\end{array}$ & $\begin{array}{l}1.015^{* * *} \\
(0.176)\end{array}$ & $\begin{array}{c}-1.551 * * * \\
(0.440)\end{array}$ & $\begin{array}{c}0.692 * * * \\
(0.213)\end{array}$ & $\begin{array}{c}1.103 * * * \\
(0.374)\end{array}$ & $\begin{array}{c}0.933^{* * *} \\
(0.154)\end{array}$ & $\begin{array}{c}1.133^{* * *} \\
(0.306)\end{array}$ & $\begin{array}{c}0.816^{* * *} \\
(0.268)\end{array}$ & $\begin{array}{l}1.415^{*} \\
(0.762)\end{array}$ & $\begin{array}{c}0.710 * * * \\
(0.236)\end{array}$ & $\begin{array}{c}1.189 * * * \\
(0.403)\end{array}$ \\
\hline \multicolumn{13}{|l|}{$\begin{array}{l}\text { Repayment agreement } \\
\text { (ref. = no agreement) }\end{array}$} \\
\hline $50 \%$ agreement & $\begin{array}{c}1.315^{* * *} \\
(0.164)\end{array}$ & $\begin{array}{l}0.0415 \\
(0.207)\end{array}$ & $\begin{array}{c}1.461^{* * *} \\
(0.179)\end{array}$ & $\begin{array}{l}-0.189 \\
(0.323)\end{array}$ & $\begin{array}{c}1.387^{* * *} \\
(0.185)\end{array}$ & $\begin{array}{l}-0.148 \\
(0.224)\end{array}$ & $\begin{array}{c}1.346 * * * \\
(0.214)\end{array}$ & $\begin{array}{l}0.213 \\
(0.367)\end{array}$ & $\begin{array}{c}1.604^{* * *} \\
(0.286)\end{array}$ & $\begin{array}{r}-0.0854 \\
(0.457)\end{array}$ & $\begin{array}{c}1.393^{* * *} \\
(0.264)\end{array}$ & $\begin{array}{c}-0.283 \\
(0.663)\end{array}$ \\
\hline $100 \%$ agreement & $\begin{array}{c}2.224 * * * \\
(0.248)\end{array}$ & $\begin{array}{l}-0.346 \\
(0.527)\end{array}$ & $\begin{array}{c}2.494 * * * \\
(0.273)\end{array}$ & $\begin{array}{l}-0.394 \\
(1.318)\end{array}$ & $\begin{array}{c}2.362 * * * \\
(0.274)\end{array}$ & $\begin{array}{l}-0.235 \\
(0.267)\end{array}$ & $\begin{array}{c}2.225 * * * \\
(0.278)\end{array}$ & $\begin{array}{l}-0.209 \\
(0.495)\end{array}$ & $\begin{array}{c}2.675 * * * \\
(0.400)\end{array}$ & $\begin{array}{c}0.148 \\
(0.631)\end{array}$ & $\begin{array}{c}2.278 * * * \\
(0.372)\end{array}$ & $\begin{array}{l}-0.222 \\
(0.571)\end{array}$ \\
\hline
\end{tabular}


Interaction of contract type with transferability of training

Temporary with prospects*In own sector

$\begin{array}{cc}-0.189 & 0.544 \\ (0.311) & (0.444) \\ -0.186 & -1.195 \\ (0.302) & (1.017) \\ -0.113 & -0.345 \\ (0.362) & (1.697) \\ 0.220 & -0.236 \\ (0.338) & (0.506)\end{array}$

Temporary with prospects*In own organisation

Temporary without prospects*In own sector

Temporary without prospects*In own organisation

$(0.338$

$0.506)$

Interaction of contract type with financial contribution

Temporary with prospects* $€ 200$

Temporary with prospects* $€ 400$

Temporary without prospects* $€ 200$

Temporary without prospects* $€ 400$

Interaction of contract type with repayment agreement

Temporary with prospects $* 50 \%$ agreement

Temporary with prospects* $100 \%$ agreement

Temporary without prospect*50\% agreement

Temporary without prospect*100\% agreement

Observations

$6,106 \quad 6,106$

1,032 1,032
6,106
Individuals 1,032

6,106 1,032
0.259

(0.270)

$0.689 * *$

(0.307)

0.0795

(0.350)

$-0.0118$

(0.324)

$-0.565^{*}$

(0.296)

$-1.263^{* *}$

(0.501)

1.077

(1.879)

0.317

(0.398)

$\begin{array}{cc}-0.154 & 0.980 \\ (0.374) & (0.705) \\ -0.0944 & 1.013 \\ (0.352) & (2.157) \\ -0.420 & -1.355 \\ (0.569) & (1.182) \\ 0.251 & 0.561 \\ (0.471) & (2.950)\end{array}$

6,106

6,106
1,032

6,106

1,032

$\begin{array}{cccccc}-0.0312 & -0.439 & -0.0627 & -0.0685 & -0.0215 & 0.574 \\ (0.278) & (0.510) & (0.390) & (0.322) & (0.319) & (0.689) \\ 0.103 & 1.252^{* *} & 0.124 & -0.362 & 0.168 & 0.423 \\ (0.299) & (0.605) & (0.346) & (0.752) & (0.327) & (1.206) \\ 0.169 & -0.991 & 0.449 & 1.297 & 0.156 & 0.215 \\ (0.316) & (1.010) & (0.440) & (1.118) & (0.423) & (4.277) \\ 0.354 & 0.290 & 0.938^{*} & -0.0985 & 0.315 & -0.381 \\ (0.334) & (0.364) & (0.554) & (0.569) & (0.432) & (1.235) \\ & & & & & \\ 6,106 & 6,106 & 6,106 & 6,106 & 6,106 & 6,106 \\ 1,032 & 1,032 & 1,032 & 1,032 & 1,032 & 1,032\end{array}$

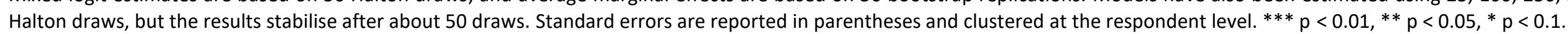


Table 4: Willingness to invest in different types of contracts under varying combinations of financial contributions and repayment agreements

Willingness to invest in training

\begin{tabular}{|c|c|c|c|}
\hline Permanent contract & $0 \%$ repayment & $50 \%$ repayment & $100 \%$ repayment \\
\hline \multirow[t]{2}{*}{$€ 0$ contribution } & $0.460 * * *$ & $0.629 * * *$ & $0.732 * * *$ \\
\hline & $(0.0223)$ & $(0.0190)$ & $(0.0210)$ \\
\hline \multirow[t]{2}{*}{$€ 200$ contribution } & $0.530 * * *$ & $0.697 * * *$ & $0.790 * * *$ \\
\hline & $(0.0174)$ & $(0.0197)$ & $(0.0194)$ \\
\hline \multirow[t]{2}{*}{$€ 400$ contribution } & $0.544 * * *$ & $0.705^{* * *}$ & $0.795 * * *$ \\
\hline & $(0.0215)$ & $(0.0176)$ & $(0.0184)$ \\
\hline Temporary contract with prospects & $0 \%$ repayment & $50 \%$ repayment & $100 \%$ repayment \\
\hline \multirow[t]{2}{*}{$€ 0$ contribution } & $0.335^{* * *}$ & $0.486 * * *$ & $0.615^{* * *}$ \\
\hline & $(0.0155)$ & $(0.0202)$ & $(0.0191)$ \\
\hline \multirow[t]{2}{*}{$€ 200$ contribution } & $0.431 * * *$ & $0.591 * * *$ & $0.713^{* * *}$ \\
\hline & $(0.0216)$ & $(0.0182)$ & $(0.0164)$ \\
\hline \multirow{2}{*}{$€ 400$ contribution } & $0.494 * * *$ & $0.645^{* * *}$ & $0.754 * * *$ \\
\hline & $(0.0195)$ & $(0.0215)$ & $(0.0177)$ \\
\hline Temporary contract without prospects & $0 \%$ repayment & $50 \%$ repayment & $100 \%$ repayment \\
\hline \multirow[t]{2}{*}{$€ 0$ contribution } & $0.142 * * *$ & $0.268 * * *$ & $0.369 * * *$ \\
\hline & $(0.0127)$ & $(0.0226)$ & $(0.0217)$ \\
\hline \multirow[t]{2}{*}{$€ 200$ contribution } & $0.192 * * *$ & $0.332 * * *$ & $0.436 * * *$ \\
\hline & $(0.0186)$ & $(0.0203)$ & (0.0209) \\
\hline \multirow[t]{2}{*}{$€ 400$ contribution } & $0.196 * * *$ & $0.332 * * *$ & $0.433 * * *$ \\
\hline & (0.0198) & $(0.0220)$ & (0.0193) \\
\hline
\end{tabular}

The coefficients represent predicted probabilities, calculated by using the observed values for the covariates that are not part of the trade-off. Standard errors are reported in parentheses and clustered the respondent level. Underlying mixed logit estimates are based on 50 Halton draws, and predicted probabilities are based on 50 bootstrap replications. $* * * \mathrm{p}<0.01, * * \mathrm{p}<0.05, * \mathrm{p}<0.1$ 
Table 5: Robustness of employers' lower willingness to invest in temporary workers

\begin{tabular}{|c|c|c|c|c|c|}
\hline & (1) & $(2)_{1}$ & (3) & (4) & (5) \\
\hline \multicolumn{6}{|l|}{ Willingness to invest in training } \\
\hline \multicolumn{6}{|l|}{ Contract type (ref. = permanent) } \\
\hline \multirow[t]{2}{*}{ Temporary with prospects } & $-0.0654^{* *}$ & $-0.0925 * * *$ & $-0.0946 * * *$ & $-0.110 * * *$ & $-0.0945 * * *$ \\
\hline & $(0.0309)$ & $(0.0258)$ & $(0.0127)$ & $(0.0181)$ & $(0.0126)$ \\
\hline \multirow[t]{2}{*}{ Temporary without prospects } & $-0.310 * * *$ & $-0.350 * * *$ & $-0.352 * * *$ & $-0.341 * * *$ & $-0.355^{* * *}$ \\
\hline & $(0.0311)$ & $(0.0269)$ & $(0.0129)$ & $(0.0176)$ & $(0.0127)$ \\
\hline \multicolumn{6}{|l|}{ Interaction with employers' perceptions } \\
\hline Temporary with prospects* & & 0.0649 & & & \\
\hline Negative perception about learning ability & & $(0.0704)$ & & & \\
\hline Temporary with prospects* & & 0.0277 & & & \\
\hline Negative perception about learning motivation & & $(0.0394)$ & & & \\
\hline Temporary with prospects* & & -0.0460 & & & \\
\hline Negative perception about both learning ability and motivation & & $(0.0358)$ & & & \\
\hline Temporary without prospects* & & 0.0347 & & & \\
\hline Negative perception about learning ability & & $(0.0611)$ & & & \\
\hline Temporary without prospects* & & -0.0171 & & & \\
\hline Negative perception about learning motivation & & $(0.0409)$ & & & \\
\hline Temporary without prospects* & & -0.0560 & & & \\
\hline Negative perception about both learning ability and motivation & & $(0.0373)$ & & & \\
\hline Controls for transferability, financial contribution, and repayment agreement & Yes & Yes & Yes & Yes & Yes \\
\hline Observations & 1,516 & 6,106 & 4,820 & 3,442 & 6,068 \\
\hline Individuals & 257 & 1,032 & 1,022 & 947 & 1,032 \\
\hline
\end{tabular}

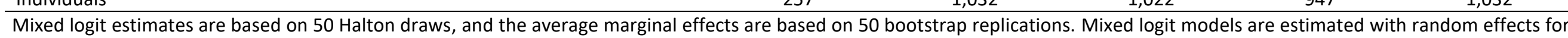

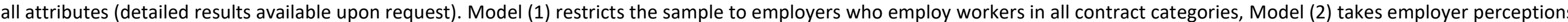

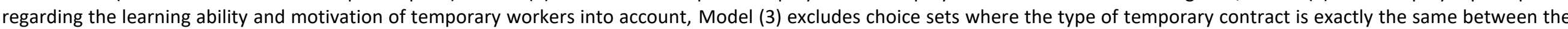

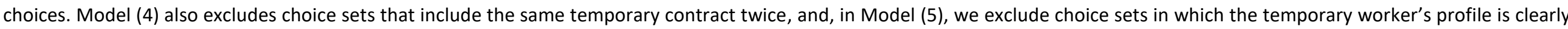
dominated by the permanent worker's.

1 Based on a linear probability model for ease of interpretation. 
Table 6: Robustness to different estimation techniques

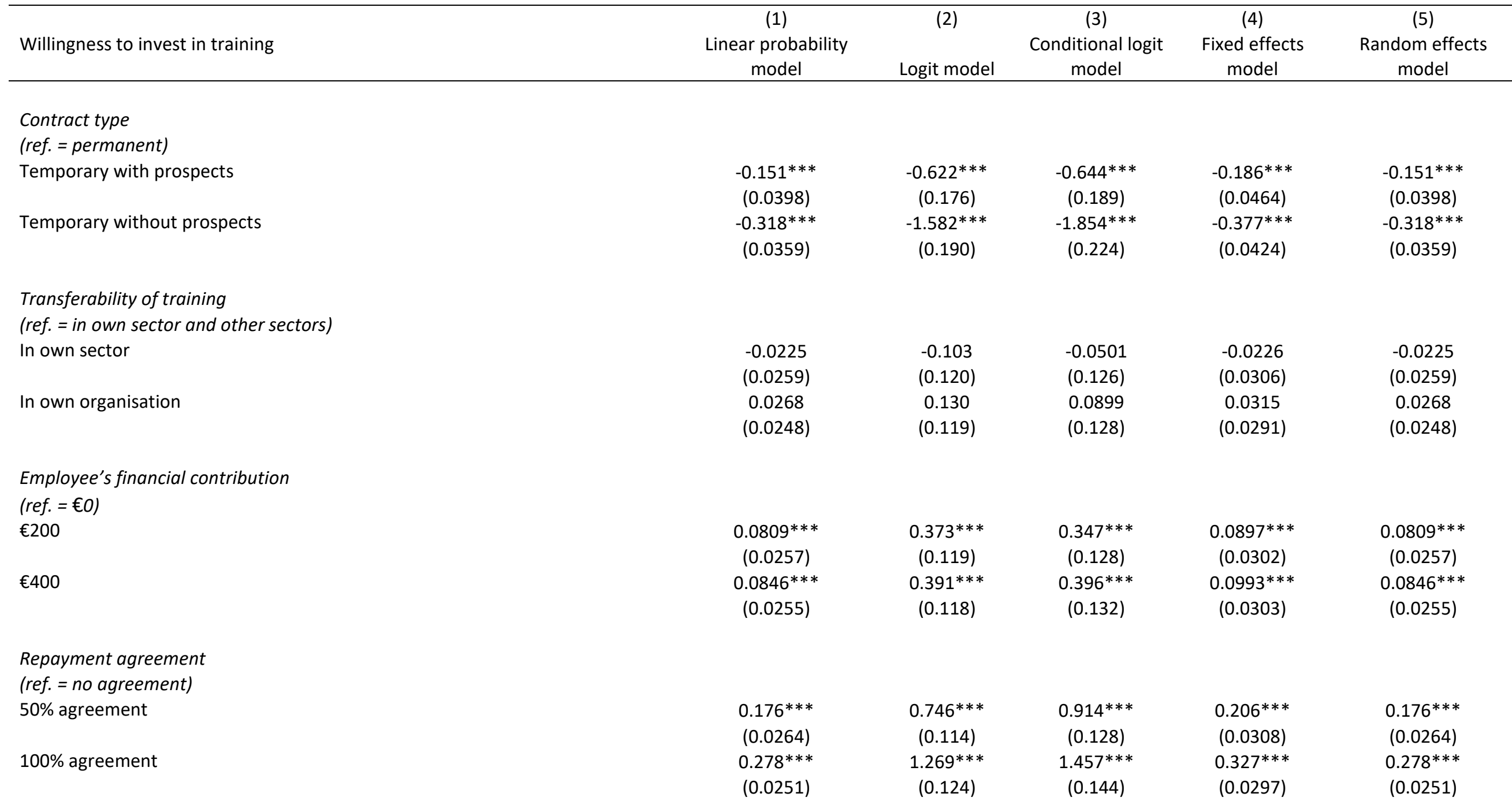


Interaction of contract type with transferability of training

Temporary with prospects*In own sector

$\begin{array}{ccccc}0.0225 & 0.103 & 0.0601 & 0.0284 & 0.0225 \\ (0.0373) & (0.168) & (0.177) & (0.0443) & (0.0373) \\ 0.0148 & 0.0504 & 0.105 & 0.0214 & 0.0148 \\ (0.0347) & (0.159) & (0.179) & (0.0410) & (0.0347) \\ -0.00810 & -0.0557 & -0.124 & -0.0163 & -0.00810 \\ (0.0352) & (0.174) & (0.182) & (0.0414) & (0.0352) \\ -0.0203 & -0.0965 & -0.0519 & -0.0278 & -0.0203 \\ (0.0344) & (0.170) & (0.186) & (0.0404) & (0.0344)\end{array}$

Interaction of contract type with financial contribution

Temporary with prospects* $€ 200$

Temporary with prospects* $€ 400$

Temporary without prospects*€200

Temporary without prospects*€400

$\begin{array}{ccccc}0.0585 & 0.227 & 0.204 & 0.0787^{*} & 0.0585 \\ (0.0367) & (0.165) & (0.177) & (0.0428) & (0.0367) \\ 0.0873^{* *} & 0.353^{* *} & 0.372^{* *} & 0.104^{* *} & 0.0873^{* *} \\ (0.0355) & (0.161) & (0.176) & (0.0417) & (0.0355) \\ -0.0254 & -0.0816 & -0.0166 & -0.0232 & -0.0254 \\ (0.0364) & (0.181) & (0.195) & (0.0431) & (0.0364) \\ -0.0314 & -0.113 & -0.0293 & -0.0420 & -0.0314 \\ (0.0355) & (0.177) & (0.196) & (0.0424) & (0.0355)\end{array}$

Interaction of contract type with repayment agreement

Temporary with prospects*50\% agreement

\begin{tabular}{lcccc}
-0.0283 & -0.133 & -0.211 & -0.0331 & -0.0283 \\
$(0.0380)$ & $(0.162)$ & $(0.179)$ & $(0.0451)$ & $(0.0380)$ \\
0.00503 & -0.0601 & -0.0473 & 0.0122 & 0.00503 \\
$(0.0353)$ & $(0.166)$ & $(0.179)$ & $(0.0415)$ & $(0.0353)$ \\
-0.0218 & 0.136 & 0.0364 & -0.0159 & -0.0218 \\
$(0.0346)$ & $(0.175)$ & $(0.191)$ & $(0.0405)$ & $(0.0346)$ \\
-0.0505 & -0.0635 & -0.0139 & -0.0512 & -0.0505 \\
$(0.0344)$ & $(0.179)$ & $(0.197)$ & $(0.0403)$ & $(0.0344)$ \\
6,106 & 6,106 & 6,106 & 6,106 & 6,106 \\
0.156 & & & 0.184 & \\
1,032 & 1,032 & 1,032 & 1,032 & 1,032 \\
\hline
\end{tabular}

Temporary with prospects*€400

Temporary without prospect*50\% agreement

Temporary without prospect* $€ 400$

1,032

$01, * * p<0.05, * p<0.1$ 
Figure 1: Employers' willingness to invest (average marginal effects of baseline results)

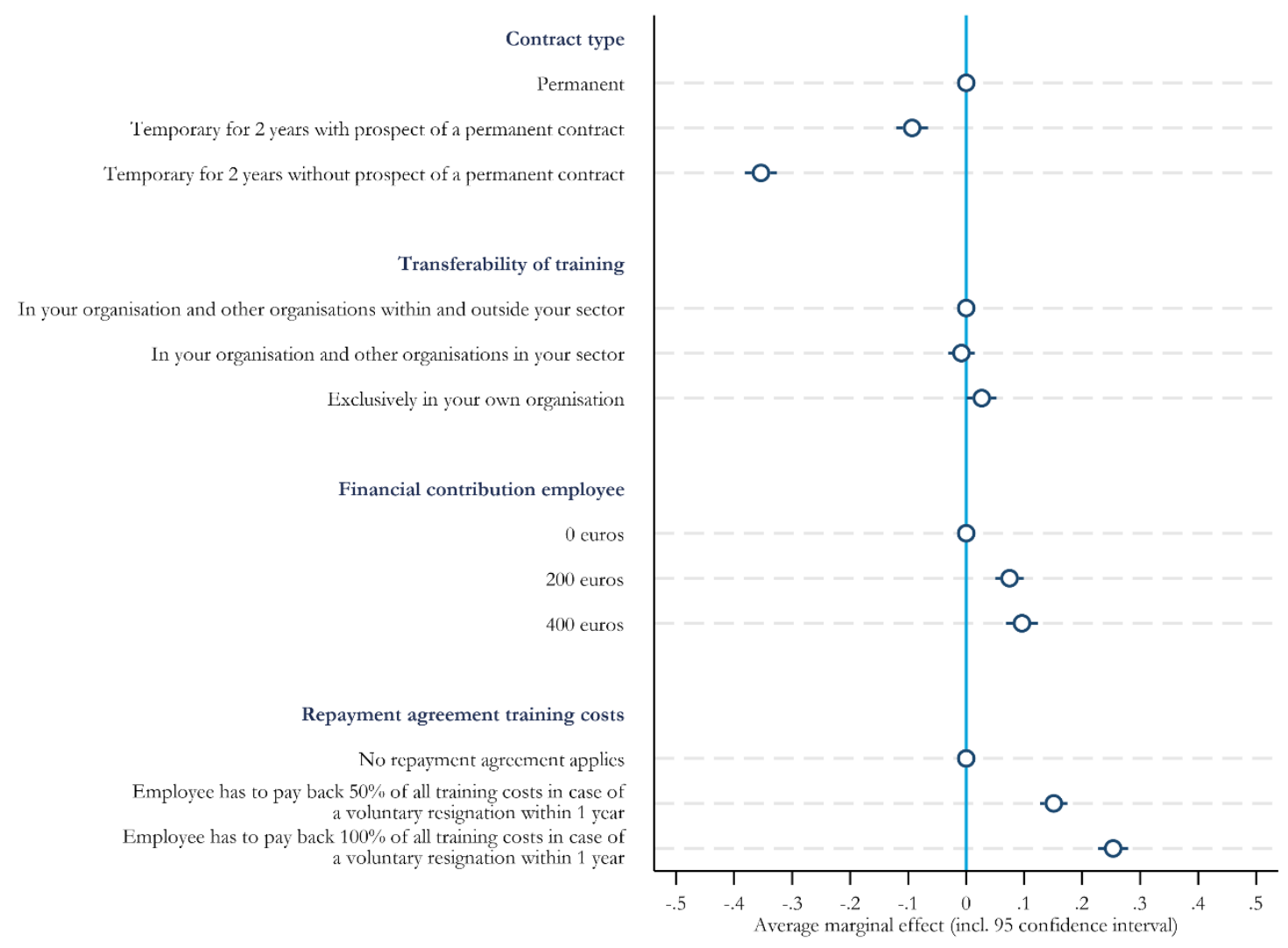

Note: This plot shows the average marginal effects of randomly assigned attributes. Marginal effects are represented by dots, based on the mixed logit model presented in Table 3, and estimated using 50 bootstrap replications. The bars represent $95 \%$ confidence intervals. Dots without confidence intervals denote the reference category of the corresponding attribute. 
Figure 2: Trade-offs between the contract type and the financial contribution (Panel $A$ ) and the repayment agreement (Panel B)

\section{Panel A}

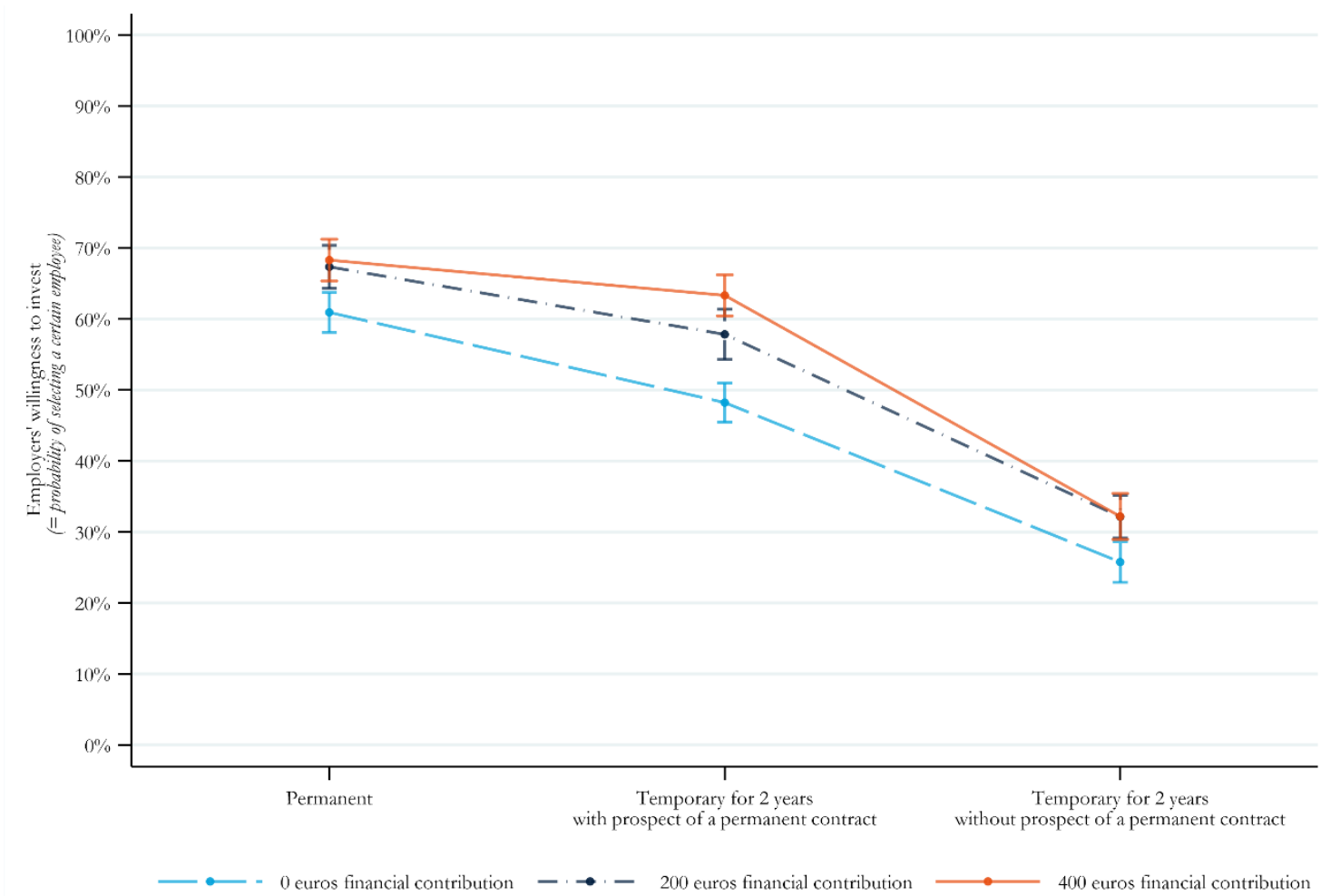

Panel B

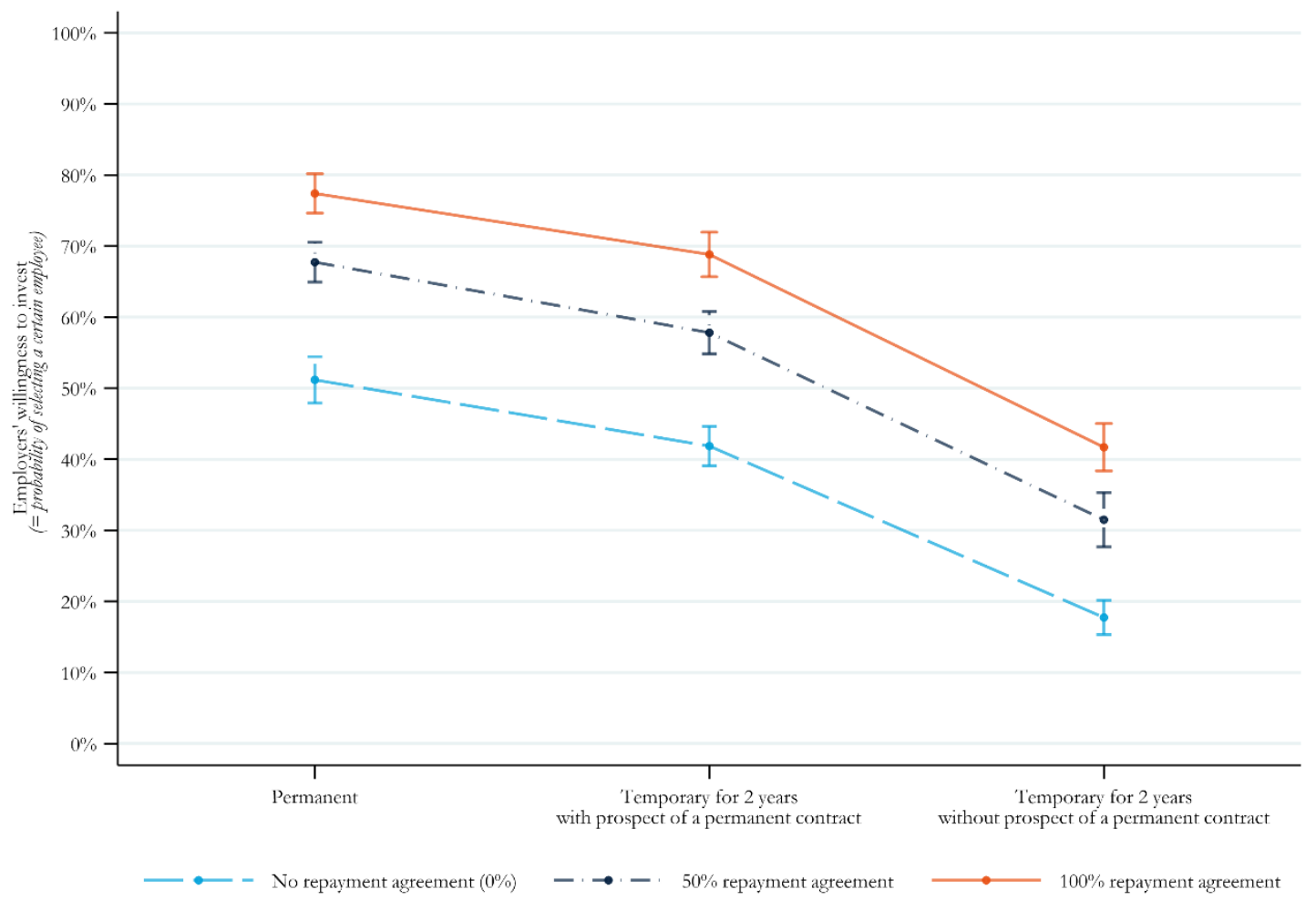

Note: Based on Table 1, Columns (3) and (4), respectively. Predicted margins are calculated using observed values for the covariates that are not part of the trade-off. 


\section{Appendix A: Introduction text and example of a discrete choice experiment}

Table A1: Introduction text and example of choice task

\section{<GENERAL INTRODUCTION PROVIDED BEFORE THE EXPERIMENT>}

You will now be presented with a number of scenarios. In each scenario you will be asked to choose between 2 employees who are eligible to be enrolled in a course/training. These employees only differ in relation to some characteristics. Otherwise, they are fully identical. We ask you to choose which of the two employees you would select for the training.

If you do not have an employee who meets the characteristics mentioned, try to imagine how you would choose if you did have an employee who fits the description.

\section{<EXPERIMENT-SPECIFIC INTRODUCTION PROVIDED TO RESPONDENTS>}

We request you [...] make 3 choices between 2 employees who are eligible for training aimed at profession specific knowledge and skills, which takes 16 hours to complete successfully and costs $€ 2,000$. [...] [T] he employees and training programme vary on the following set of characteristics and are otherwise identical:

- The type of employment contract

- Applicability of training within and outside the organisation

- The willingness of the employee to contribute financially

- The repayment agreement of training costs that applies

Which of these 2 employees do you prefer to offer the training?

\begin{tabular}{|l|l|l|}
\hline Type of contract & Employee A & Employee B \\
\hline Applicability of training & $\begin{array}{l}\text { Temporary for 2 years with } \\
\text { prospect to get a permanent } \\
\text { contract }\end{array}$ \\
\hline Financial contribution & $\begin{array}{l}\text { In your own organisation } \\
\text { and other organisations } \\
\text { within and outside your } \\
\text { sector }\end{array}$ & $\begin{array}{l}\text { Exclusively in your own } \\
\text { organisation }\end{array}$ \\
\hline Repayment agreement & No euros & Oeuros \\
\hline & $\begin{array}{l}\text { Repayment agreement of } \\
\text { 50\% in case leaves the } \\
\text { organisation voluntary within } \\
\text { 1 year }\end{array}$ \\
\hline
\end{tabular}

Employee A

Employee B 


\section{Appendix B: Learning ability and motivation}

The 2017 Employer Training Policy Survey used the following question to measure employers' perceptions regarding the average ability and motivation to learn new things (see Table B1). First, we asked them to evaluate the ability to learn. Using a similar question, we then asked them to evaluate the motivation to learn.

Table B1: Measurement of perceptions regarding learning ability and motivation

The following questions are about the motivation [ability] of employees to learn new things.

How high or low do you rate the average motivation [ability] to learn new things for the following groups of employees?

If you do not have any employees who meet these characteristics, please try to imagine how you would choose if you did.

\begin{tabular}{|l|l|l|l|l|l|}
\hline & $\begin{array}{l}1-2 \\
\text { very } \\
\text { low }\end{array}$ & 2 & 3 & 4 & $\begin{array}{l}5 \\
\text { very } \\
\text { high }\end{array}$ \\
\hline Employees with a permanent contract & $\bigcirc$ & $\bigcirc$ & $\bigcirc$ & $\bigcirc$ & $\bigcirc$ \\
\hline $\begin{array}{l}\text { Employees with a temporary contract with prospect of a } \\
\text { permanent contract }\end{array}$ & $\bigcirc$ & $\bigcirc$ & $\bigcirc$ & $\bigcirc$ & $\bigcirc$ \\
\hline $\begin{array}{l}\text { Employees with a temporary contract without prospect } \\
\text { of a permanent contract }\end{array}$ & $\bigcirc$ & $\bigcirc$ & $\bigcirc$ & $\bigcirc$ & $\bigcirc$ \\
\hline
\end{tabular}

The mean scores and standard deviations regarding employers' assessment of temporary and permanent workers are as follows:

Table B2: Mean scores and standard deviations for ability and motivation to learn

\begin{tabular}{|l|c|c|c|c|c|c|}
\hline \multirow{2}{*}{} & \multicolumn{3}{|c|}{ Motivation to learn } & \multicolumn{3}{|c|}{ Ability to learn } \\
\cline { 2 - 7 } & Mean & SD & $\mathrm{N}$ & Mean & SD & $\mathrm{N}$ \\
\hline Employees with a permanent contract & 3.36 & 0.81 & 1,032 & 3.48 & 0.70 & 1,032 \\
\hline $\begin{array}{l}\text { Employees with a temporary contract with } \\
\text { prospect of a permanent contract }\end{array}$ & 3.53 & 0.83 & 1,032 & 3.54 & 0.74 & 1,032 \\
\hline $\begin{array}{l}\text { Employees with a temporary contract without } \\
\text { prospect of a permanent contract }\end{array}$ & 2.81 & 0.99 & 1,032 & 3.06 & 0.91 & 1,032 \\
\hline
\end{tabular}

